\title{
A new validated TRNSYS module for simulating latent heat storage walls
}

Authors: $\quad$ Saleh Nasser Al-Saadi ${ }^{1}$, Zhiqiang (John) Zhai $^{2}$

${ }^{1}$ Assistant Professor, Department of Civil and Architectural Engineering, P.O. Box 33, Sultan Qaboos University, Postal code 123, Oman salsaadi@squ.edu.om, Tel.: +968 24122697; Fax: +968 24141331

${ }^{2}$ Professor, Department of Civil, Environmental, and Architectural Engineering, University of Colorado at Boulder, Boulder, CO 80309-0428, USA, John.Zhai@ colorado.edu, Tel.: +1 303 4924699; Fax: +1 3034927317 


\title{
A new validated TRNSYS module for simulating latent heat storage walls
}

\author{
Saleh Nasser Al-Saadi ${ }^{1}$, Zhiqiang (John) Zhai $^{2}$ \\ ${ }^{1}$ Civil and Architectural Engineering, P.O. Box 33, Sultan Qaboos University, 123, Oman, Tel.: \\ +968 24122697; Fax: +968 24141331 \\ ${ }^{2}$ Civil, Environmental, and Architectural Engineering, University of Colorado at Boulder, \\ Boulder, CO 80309-0428, USA, Tel.: +1 303 4924699; Fax: +1 3034927317
}

\begin{abstract}
Lightweight structures have suffered long from low thermal inertia making them more vulnerable to climatic conditions. The adoption of phase change material (PCM) can potentially reduce this climatic deficiency. In order to evaluate its thermal potential, computational modeling has shown to be promising design tools. In this paper, a new TRNSYS type is developed and validated for simulating PCM-enhanced walls. Using the validated module, it is found that the best PCM's configuration is when placed in direct contact with the indoor controlled environment. Additionally, a wide range of PCM's thermal properties were simulated under typical U.S. climates to evaluate the thermal performance and identify the optimal thermal properties. The results show that a maximum saving of $0.8-15.8 \%$ is achieved on annual cooling load depending on the climate. For heating dominated climates, the savings on annual heating load is insignificant being less than $4 \%$. The saving in peak loads was found to show more potential than annual loads for some climates. The maximum savings in peak cooling load range from $6.8-13.3 \%$ while savings in peak heating load range from 7-10.5\%. For maximum savings in zonal loads, the optimal thermal properties of PCM are found to hover around the operational thermostat setpoints.
\end{abstract}

Keywords: PCM, latent heat storage, TRNSYS, thermal performance, building envelope, building simulation 


\section{Introduction}

Latent heat storage using phase change material (PCM) is a very effective passive technique that is used to dampen the effect of heat wave. As a result, the thermal load of a zone is reduced and delayed, and consequently reducing the energy consumption. Hence, PCM has gained great attention in the past decade or so. Literature shows numerous conceptual and real examples of PCM integration into building applications [1-10]. Many studies have been conducted to evaluate the thermal and energy performance of PCM-enhanced envelopes using field testing, laboratory, and simulation packages. Different performance indicators are used to evaluate the thermal performance of PCM. A common indicator is using the peak or annual heating and cooling loads for evaluating the thermal potential of PCMs.

It is perhaps rational to integrated PCM into external wall systems due to the availability of large surface area exposed to outside climate. Since 2000, a research group lead by Medina at the University of Kansas has established experimental testing facilities, a lab dynamic simulator and computer model for evaluating PCM-enhanced walls [11-15]. Over a course of a decade of research, the group has published several studies evaluating a verity of PCM design configurations in different wall orientations. Several experimental studies conducted over summer or winter days revealed that PCM has significant reduction in peak and daily loads. The three common PCM integrations tried by the group into the wood assembly wall are: 1) PCM encapsulated in embedded copper pipe, 2) Structural Insulated Panel (PCM-SIP), 3) PCM blended with cellulose insulation. Two PCM concentrations are tested throughout these studies with various latent heats: 1) $10 \%$ of PCM, and 2) $20 \%$ of PCM concentration. The average reduction in peak heating load for all walls ranges from as low as $5.7 \%$ to as high as $15 \%$ depending on the thermal properties of PCM, PCM design configurations, PCM concentration, 
and the time period of the study. Similarly for the average space cooling load, a reduction of $9 \%$ to $11 \%$ was reported. For particular orientations, the south and west are the best for PCM integration. In one study [12], the average reduction in peak heat transfer for $10 \%$ PCM concentration was found $37 \%$ and $20 \%$ for south and west walls, respectively. For the $20 \%$ PCM concentration, the average reduction in peak heat transfer rate was $62 \%$ and $60 \%$ for south and west walls. Recent experimental results conducted by one of the group member found that the average reduction in peak heat transfer could reach as much as $27 \%$ for the four wall's orientations [15].

Over the last few decades, new PCM products have emerged into building industry. An experimental testing facility was built at Arizona State University to evaluate one commercial PCM product [16]. The PCM panels were installed on every surface of the test shed on the interior side. Over the course of many months of testing under Phoenix climate, the results show a reduction of $27 \%$ in peak cooling load and a reduction of $19 \%$ in annual cooling energy. Since no internal heat gain are imposed except the solar radiation from a single east window, the high surface area of PCM has to exclusively handle the cooling load generated by the heat transfer from outside climate through exterior envelope.

Using the Natural Exposure Testing facility located in Charleston in south California, two testing campaigns in summer and winter have been conducted to evaluate the performance of different PCM panels divided into two wall groups under real climatic conditions [17]. Results from wall group-1 indicated an increase in both heat gain and heat losses in summer and winter periods, respectively. The authors have indicated that the temperature and heat flux sensors installed in this wall category may have been jeopardized by the air gap that resulted in erroneous readings. The results from the other wall group show a reduction in heat gain that 
ranges between $21.8-22.9 \%$ in summer. In winter, the reduction in heat gain ranges from $5.7 \%$ $15.4 \%$ and a reduction in heat loss from $25.5-27.7 \%$ have been reported. The results from winter and summer campaigns have been reported on 30 days period.

Validated simulation tools have also been used to evaluate the energy performance of PCM in buildings. Among validated tools, EnergyPlus is a common design tool that has dominated the recent research studies. After rigorous validation efforts, National Renewable Energy Laboratory (NREL) research team has used EnergyPlus to simulate the PCM integrations into different envelope systems using a typical house as per America benchmark protocols under Phoenix, AZ weather file[18]. The results show that PCM has minor effect on reducing the peak cooling load in the cooling season of Phoenix. For the best PCM application in the wall, a maximum reduction of around $8 \%$ in peak cooling was achieved in the month of May with only $4 \%$ peak cooling reduction in July. A couple of hospital spaces including administration office space, group treatment and patient rooms have been individually simulated using EnergyPlus for Oregon State Hospital in Junction City [19]. PCM layers with different thermal properties are integrated into these spaces for three envelope options: 1) external walls only, 2) external walls and ceiling, 3) all surfaces. The charging occurs naturally during the day but discharging is performed using night flush via integrated economizer with HVAC system. Average reduction of $15 \%, 17 \%$ and $28 \%$ in annual cooling energy, and $9.5 \%, 11 \%, 12 \%$ reduction in peak cooling load are achieved for external walls only, external walls and ceiling deign option, and all surfaces option respectively.

A simulation study using EnergyPlus has been conducted for office space under the climate of Seol, Korea [20]. Four PCM layers with different melting temperatures integrated into insulated lightweight wall has been studied. With all PCM types, annual heating loads have 
marginally increased but peak loads has decreased by $3.2 \%$ for $\mathrm{PCM}$ with $21^{\circ} \mathrm{C}$ melting temperature. The maximum reduction of $1.2 \%$ in annual cooling load and a maximum reduction of $1.3 \%$ in peak cooling load were achieved. The PCMs with melting temperature close to the heating and cooling setpoints $\left(\mathrm{Thtg}=22^{\circ} \mathrm{C}, \mathrm{Tclg}=26^{\circ} \mathrm{C}\right)$ are showing the highest potential. The study further uses the natural ventilation to discharge the absorbed heat. On average for all PCM layers, a reduction of $9 \%$ and $10.5 \%$ are achieved for annual cooling and peak cooling load, respectively. However, a $7.5 \%$ reduction in annual cooling load and a reduction of $10.2 \%$ in peak cooling load are solely due to natural ventilation. Another simulation study using EnergyPlus was performed for a residential flat under a tropical climate of Hong Kong [21]. The simulation study has indicated a reduction of only $2.9 \%$ in annual cooling energy. The study concluded that the PCM installation in this climate is not feasible due to the long payback period.

Few proprietary simulation packages have also been used to evaluate energy savings potential of PCM in buildings. At the University of Dayton, Kissock and co-workers [22] built a testing facility solely to validate a PCM numerical model [22]. The team used this validated model to study the impact of PCM integration into concrete sandwiched walls [23]. The peak and annual cooling loads were reduced by $19 \%$ and $13 \%$, respectively. When PCM is discharged using cold air via natural ventilation, the annual cooling load could be reduced by as much as 17\%; a 4\% enhancement. A simulation study using RADCOOL found that a PCM integrated into wallboard can reduce the peak cooling load by $28 \%$ in California climate for a typical office building[24]. The claimed savings can be facilitated when PCM is coupled with mechanical night ventilation. In another simulation study for a coastal climate of California, Lee has used a validated computer model to evaluate the potential of PCM [15]. The study concluded that the average reduction in peak heat transfer rate of all four walls can reach $12 \%$. 
A simulation study using HEATING 8 has been conducted to evaluate the PCM performance for two US climates: Phoenix, AZ and Baltimore, MD [25]. The study has investigated many PCM's design configurations in a base residential wall case and various thermal properties for four wall orientations individually. The main focus of the study was to evaluate the potential in reducing the cooling energy. The study found that when PCM placed to the interior side achieves slightly better performance but is sensitive to the zonal thermostat setpoint. When PCM is blended with full insulation thickness, the performance is less sensitive. For PCM full thickness, the reduction in wall-related cooling electricity ranges from 6-10\% and 35-62\% for Phoenix and Baltimore, respectively. For both climates, west and south orientations are the best for PCM integration. For Phoenix, the optimal melting temperature range is about $2{ }^{\circ} \mathrm{C}$ and $1{ }^{\circ} \mathrm{C}$ above cooling setpoint (i.e., $25^{\circ} \mathrm{C}$ ) for North and East walls and about $1{ }^{\circ} \mathrm{C}$ above cooling setpoint for South and West. For Baltimore climate, the optimal midpoint temperature is always at the cooling setpoint temperature.

Athienitis [26] has validated a numerical model for evaluating gypsum board soaked in PCM using a testing facility built in Montreal, Canada. The savings in total heating load was predicted to be $15 \%$ under the cold climatic condition of Montreal. Utilizing a self-developed computer model, a small room was modeled using Algeria weather file [27]. The study found that a maximum reduction in annual cooling energy and peak cooling load are $1 \%$ achieved with $24.5^{\circ} \mathrm{C}$ melting temperature and $24 \%$ achieved with $33.2^{\circ} \mathrm{C}$ melting temperature, respectively. In addition, a maximum reduction of $12.8 \%$ in annual heating energy and a $35.4 \%$ reduction in peak heating load are achieved using $\mathrm{PCM}$ with $19.8^{\circ} \mathrm{C}$ and $19^{\circ} \mathrm{C}$ melting temperature, respectively. 
Table 1 summarizes the results from the field, laboratory and simulation studies. It is observed that none of experimental studies have considered internal heat loads in the evaluation. In these cases, PCM deals with outside climate as a source of heat that has to be manipulated. Since the climate drives the charging and discharging process, PCM has proven to offer significant thermal potential. Building simulation programs offer more flexibility to model real prototype with complex boundary conditions. However, results from whole building simulation programs have indicated that PCM underperforms in prototype house models with realistic boundary conditions. The thermal potential of PCM is not equally materialized when compared to small scale room prototype. This observation has recently been highlighted by a simulation study that demonstrated insignificant energy savings when a real typical house is simulated compared to a single room house [28]. In a housing model under typical boundary conditions, several dynamic factors influence the PCM's thermal performance. For instant in hot summer season, PCM has to handle many heat sources including internal heat gain, solar radiation and heat transfer through conduction from outside climate. Tackling many heat sources with no mechanism to discharge the stored heat quickly depletes the PCM's storage capacity. Enhancing the discharging process using outside cooled air, for example, appears to be promising technique to flush the stored heat. In cold winter season, more heat sources are desirable where some are instantaneously utilized to meet the heating demand and surplus heat can be stored by PCM for later use. In mild climates, the charging and discharging process techniques are passively realized with no external manipulation. Hence, PCM is thermally more appealing in the mild transition season compared to extreme hot or cold seasons.

In general, the various studies indicate that the PCM's performance is highly dependent on many factors including the PCM's thermal properties (i.e., latent heat, melting temperature, 
and melting range), zonal thermostat setpoints, PCM's design configurations and integration mechanism, the insulation level of the wall assembly, PCM's surface areas, exposure to internal heat and solar gains, charging and discharging strategies and the climate. The balance between these factors will lead to enhanced PCM's performance. Computational modeling is attractive design tool that can be utilized to optimize these factors. Although whole building simulation tools such as EnergyPlus [29], TRNSYS [30], ESP-r [31] etc. are capable of simulating dynamic systems, they still lack algorithms that are fast, accurate and numerically stable for modeling PCM [32]. A recent study pointed out limitations and provided guidelines when simulating PCMs using EnergyPlus [18]. Similar limitations exist for other building simulation tools such as TRNSYS [33] and ESP-r [34]. These shortcomings have been identified recently by a group of experts among the International Energy Agency's (IEA) Annex 23 team members who concluded, based on their comprehensive review on PCM's modeling, that the confidence in PCM's models is too low to use for future building's behavior [35]. Moreover, the reviewed models are not tested in a very stringent or exhaustive way.

In light of the above reviews, the motivation for this study is to develop a numerical model that is capable of simulating PCM-enhanced walls in buildings. For several reasons highlighted in the next section, the developed model will be integrated into TRNSYS, a wholebuilding simulation program [30]. The model will then be validated using experimental data from literature. Based on this validated model, a typical residential house will be modeled with PCM-enhanced walls under four U.S. representative climates. The results from this study would be very valuable to design engineers and architects to select effective PCM's thermal properties to achieve maximum savings in heating and cooling loads. 


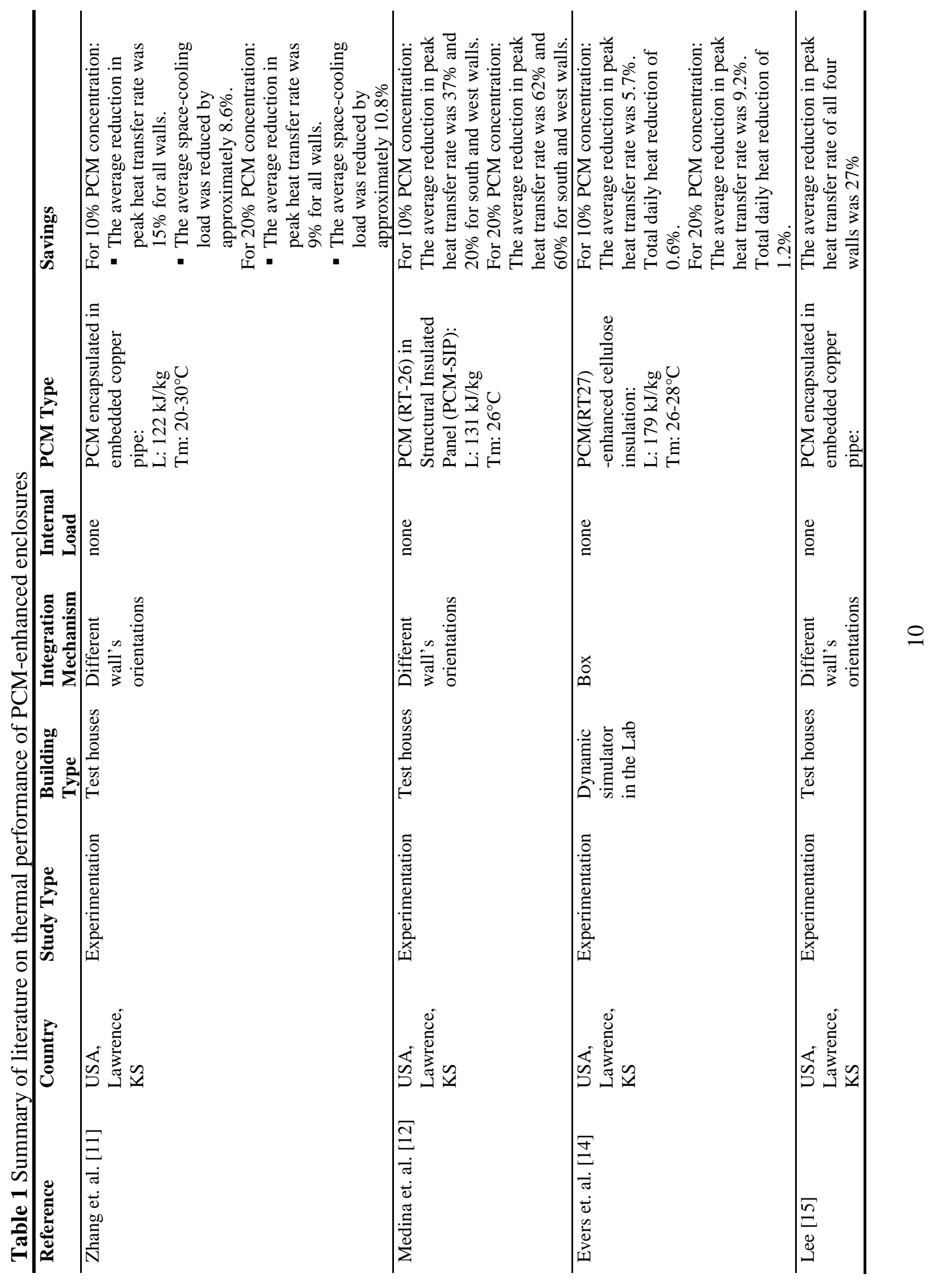




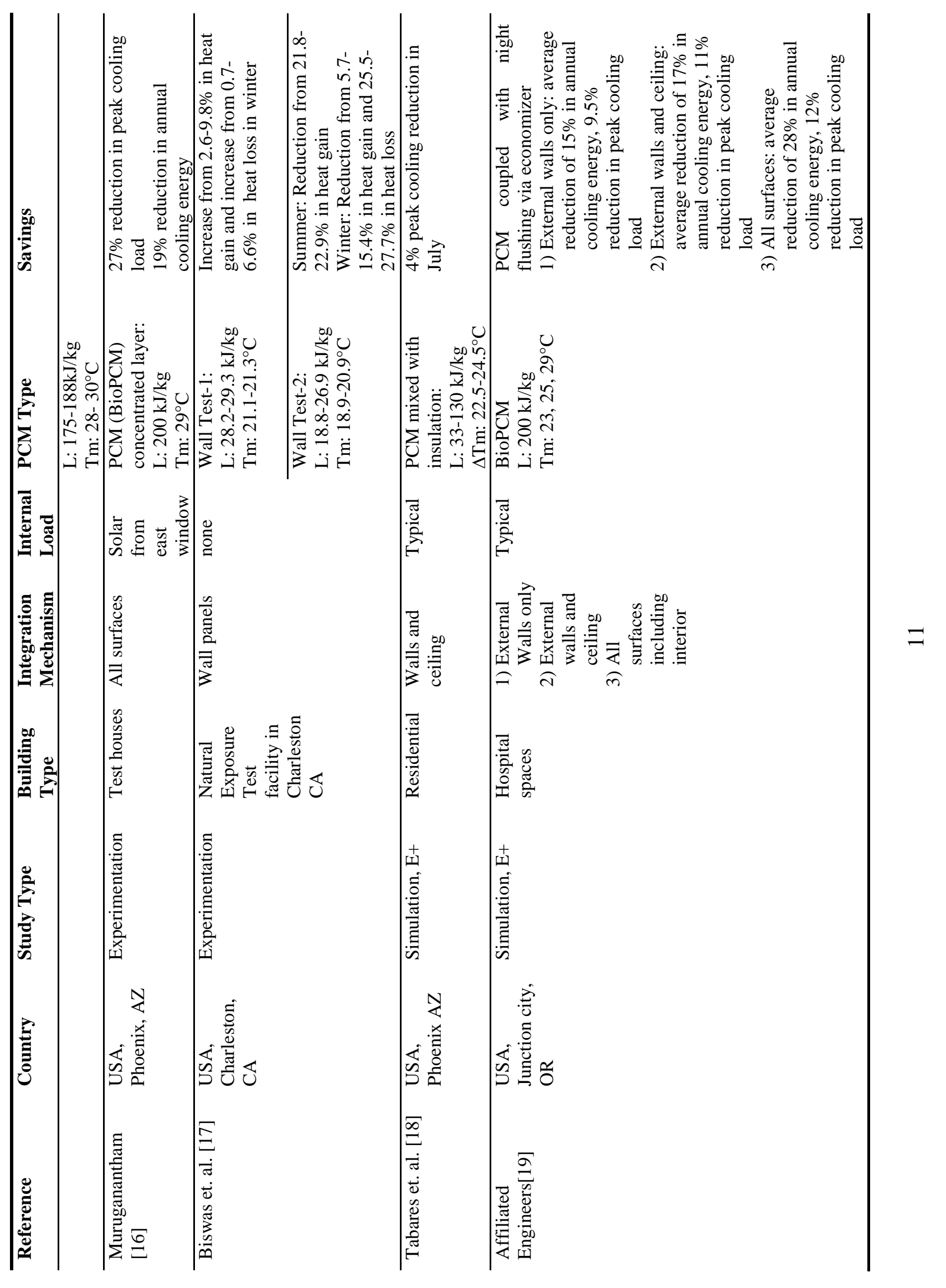




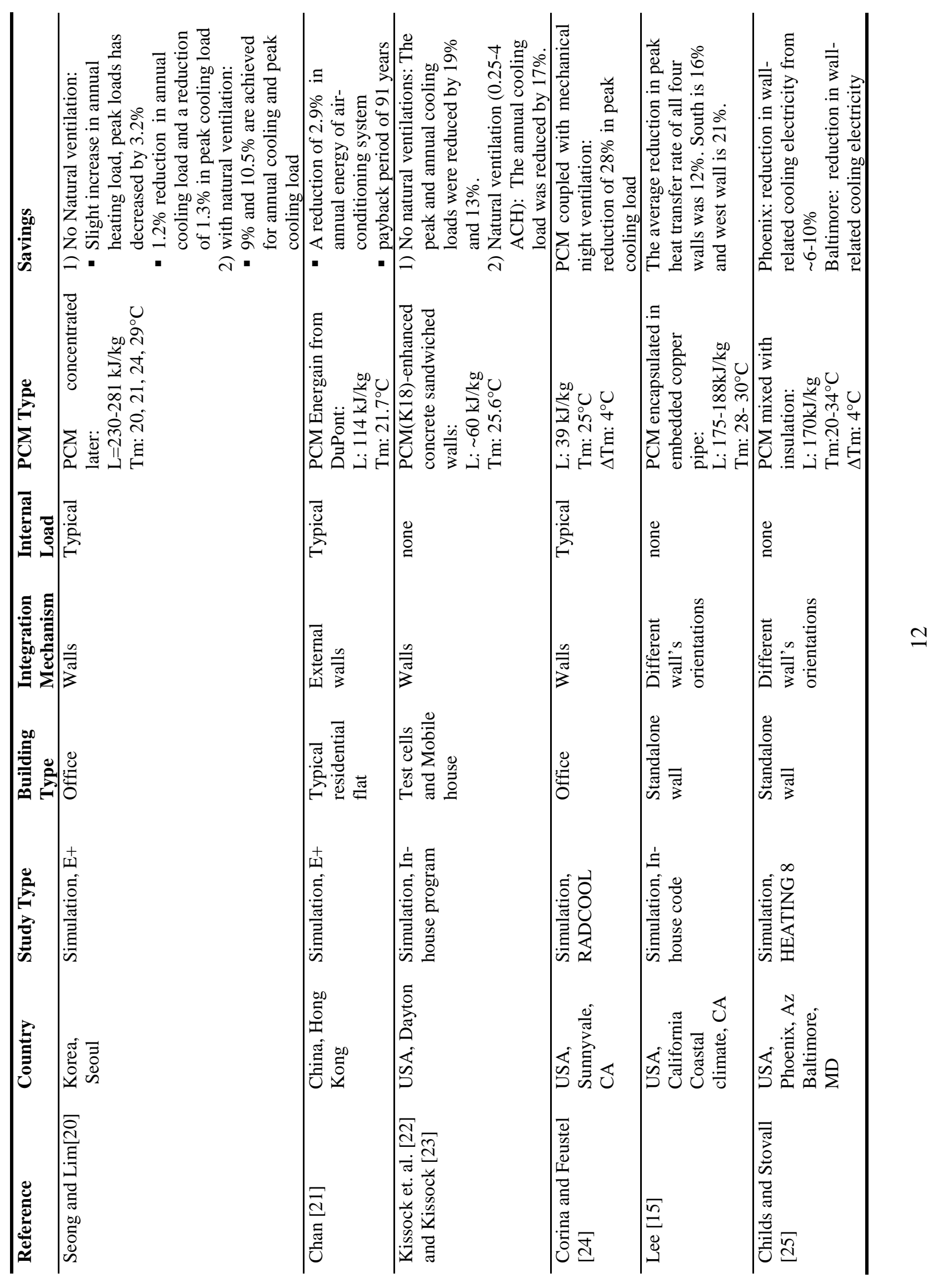




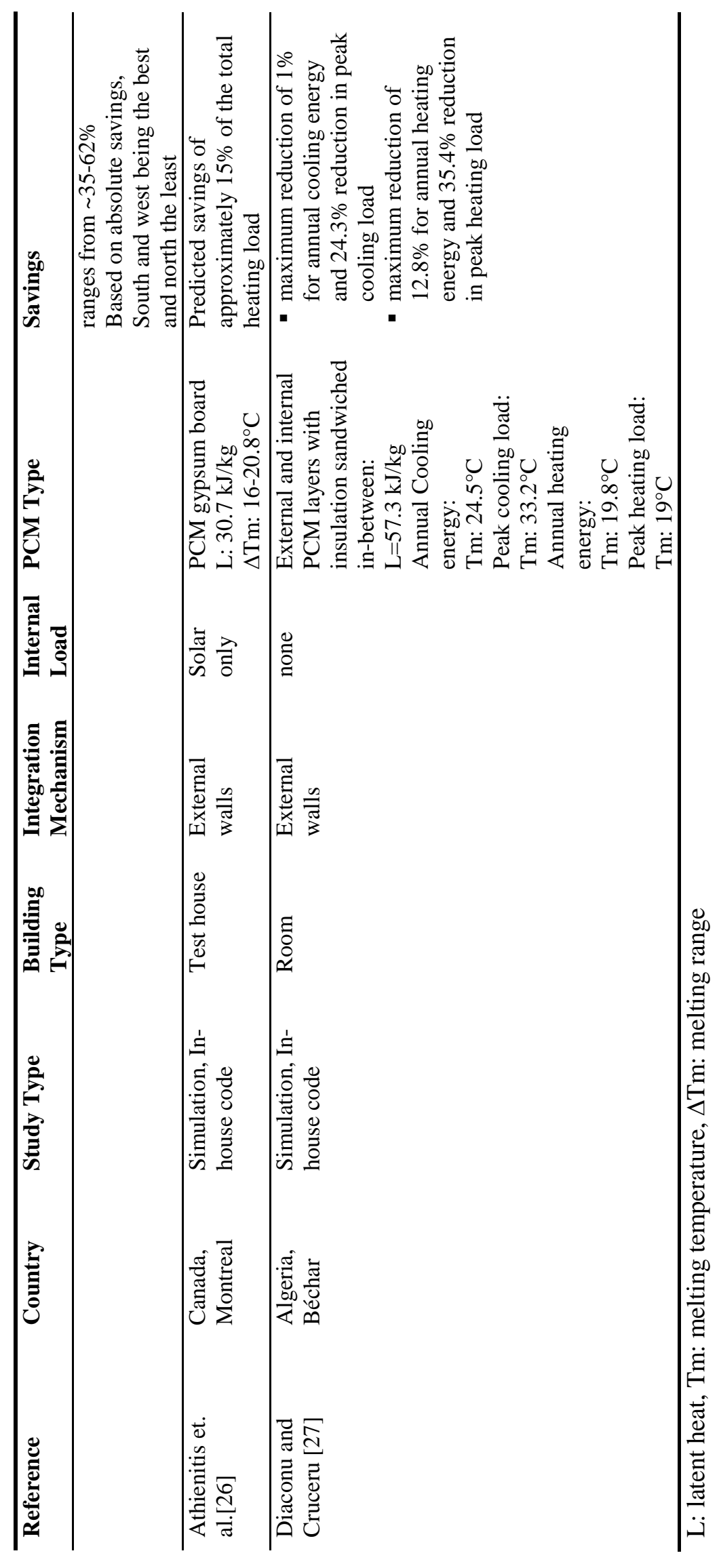




\section{Methodology}

\subsection{Simulation Tool}

Unlike field studies, computational modeling is inexpensive yet an effective tool for analyzing, optimizing and fine tuning final designs of PCMs in building applications. This study utilizes a computation approach using TRNSYS for modeling PCM. Many features have been introduced into TRNSYS, including a graphical user interface "Simulation studio" and the possibility to call external programs such as MATLAB, FLUENT and many others [30]. TRNSYS is a modular program where components "TYPES" are linked together in which output of one type can be an input to another in the model. Due to its modularity, proprietary "TYPES" for modeling PCM have been successfully developed in this simulation package [32]. Therefore, this simulation package has been selected in this study.

\subsection{Integration mechanism for modeling PCM-enhanced wall in TRNSYS}

For modeling a building in TRNSYS, two generic modules are available; a multi-zone Type-56 and a simplified single zone Type-19. Since it provides detailed physics for modeling buildings, the developer recommends the use of Type-56 even for a single zone building [36]. The multi-zone Type 56 uses transfer function method (TFM) to approximate the heat transfer mechanism across building envelope. However, TFM can't handle the latent heat evolution but TRNSYS provides flexibility to integrate specially designed façade system using the concept of boundary temperature in Type-56. Using this capability, a PCM-enhanced wall can externally be modeled and consequently provide the surface temperature as a boundary condition to Type 56 for indoor air heat balance calculations. Figure 1 illustrates the concept of boundary temperature between Type-56 and an externally developed wall module. Utilizing this modeling approach, 
both types exchange intermediate values in iterative process until convergence is achieved during a time step.
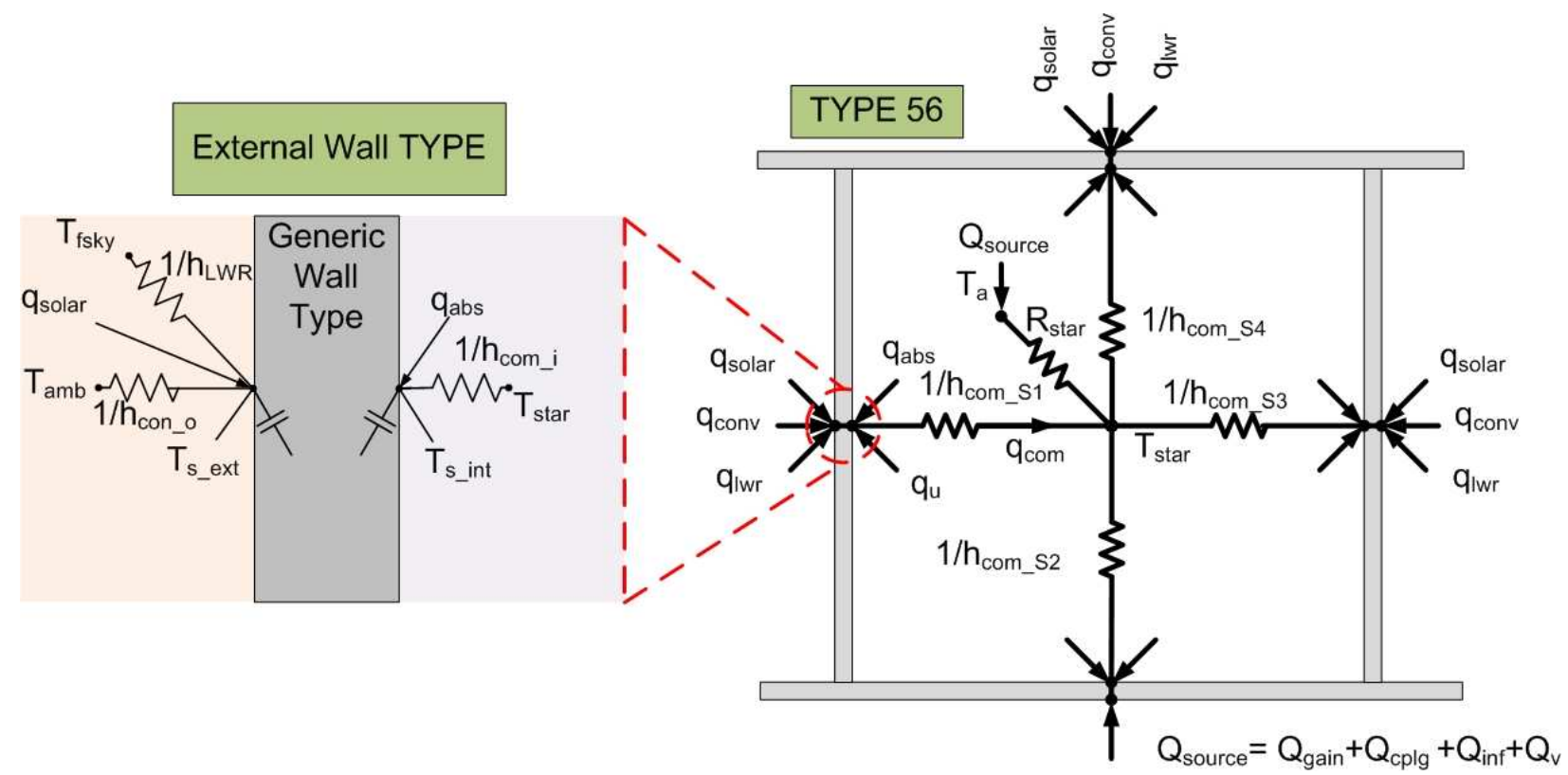

Figure1 Integration mechanism of an external wall type with Type 56 in TRNSYS

\subsection{Development of Type-285 in TRNSYS for modeling PCM-enhanced wall}

Generally speaking, any type in TRNSYS can be represented as a black box model as illustrated in Figure 2. The type can be generated using several programming languages such as FORTRAN, C or C++, MATLAB and others [30]. The type requires inputs, parameters and outputs. Inputs are necessary variables during the simulation and can be outputs from other types within TRNSYS simulation studio.

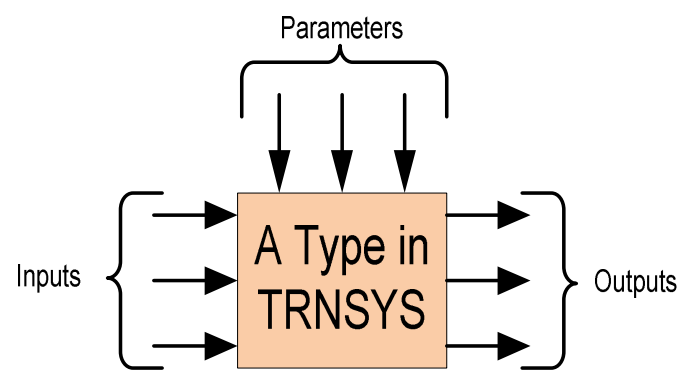

Figure 2 Black box representation of a Type in TRNSYS 
Type-285 is developed using FORTRAN programming language and compiled beforehand for use in TRNSYS. As described earlier, the developed type uses the boundary temperature concept via a massless dummy layer with a very small resistance in Type-56. Figure 3 illustrates the concept of interaction between the developed type and other components in simulation studio of TRNSYS. The wall's thermo-physical properties are provided through an external text file and necessary output data is externally saved into text files for post-processing.

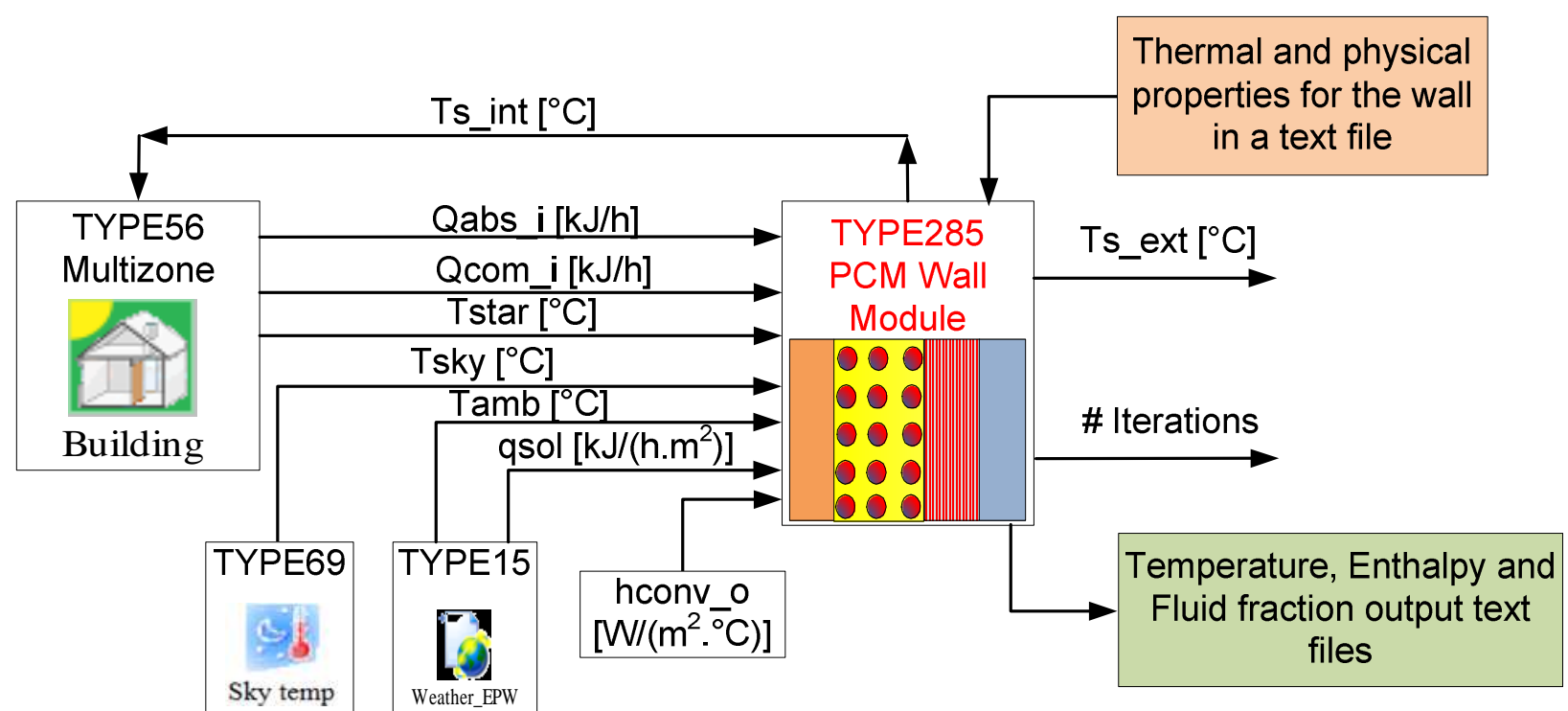

Figure 3 Configuration of Type-285 within TRNSYS simulation studio

\subsection{Numerical model: description, assumptions and validation}

\subsubsection{Model description and assumptions}

Latent heat evolution can generally be modeled using different methods; enthalpy method, heat capacity method, heat source method and others [32]. In this study, the enthalpy method is adopted for modeling PCM. For conduction-dominated heat transfer problems, the governing equation of phase change can be written in a general form as:

$\rho \frac{\partial h}{\partial t}=\frac{\partial}{\partial x}\left(k \frac{\partial T}{\partial x}\right)$ 
A fully implicit control volume approximation is used. Therefore for internal nodes, equation (1) can be discretized as follows:

$\rho \frac{h_{p}^{n+1}-h_{p}^{n}}{\Delta t}=k_{w} \frac{T_{w}^{n+1}-T_{p}^{n+1}}{\Delta X * \delta X_{w}}+k_{e} \frac{T_{e}^{n+1}-T_{p}^{n+1}}{\Delta X * \delta X_{e}}$

Collecting terms and rearranging, equation (2) becomes:

$h_{p}^{n+1}=h_{p}^{n}+a_{w} * T_{w}^{n+1}+a_{p} * T_{p}^{n+1}+a_{e} * T_{e}^{n+1}$

Where: $a_{w}=\frac{k_{w} * \Delta t}{\rho * \Delta X * \delta X_{w}}, \quad a_{e}=\frac{k_{e} * \Delta t}{\rho * \Delta X * \delta X_{e}}, \quad a_{p}=-\left(a_{w}+a_{e}\right)$

Equation (3) is nonlinear since both $h_{p}^{n+1}$ and $T^{n+1}$ are unknown at this time step. A linearization technique can be, however, utilized to solve this equation as proposed by Patankar [37]. Using this technique, the $h_{p}^{n+1}$ term can be approximated as follows:

$h_{p}^{n+1, m+1}=h_{p}^{n+1, m}+C(T)^{n+1, m} *\left(T_{p}^{n+1, m+1}-T_{p}^{n+1, m}\right)$

At the start of simulation, the temperature fields are based on guess values. Hence, the heat capacity term in equation (4) (i.e., $C(T)^{\mathrm{n}+1, \mathrm{~m}}$ ) can be found using the following relationship [38]:

$C(T)=\left\{\begin{array}{lr}C_{s} & T \leq T_{m}-\epsilon \\ \frac{C_{s}+C_{l}}{2}+\frac{L}{2 \epsilon} & T_{m}-\in<T<T_{m}+\epsilon \\ C_{l} & T \geq T_{m}+\epsilon\end{array}\right.$

When equation (4) is substituted into equation (3) and after rearrangement and collecting terms, the following linear discretized equation is derived: 


$$
\mathrm{a}_{\mathrm{w}}^{\mathrm{n}+1, \mathrm{~m}} * \mathrm{~T}_{\mathrm{w}}^{\mathrm{n}+1, \mathrm{~m}+1}+\mathrm{a}_{\mathrm{p}}^{\mathrm{n}+1, \mathrm{~m}} * \mathrm{~T}_{\mathrm{p}}^{\mathrm{n}+1, \mathrm{~m}+1}+\mathrm{a}_{\mathrm{e}}^{\mathrm{n}+1, \mathrm{~m}} * \mathrm{~T}_{\mathrm{e}}^{\mathrm{n}+1, \mathrm{~m}+1}=\mathrm{R}^{\mathrm{n}+1, \mathrm{~m}}
$$

Where:

$$
\begin{aligned}
& a_{w}^{n+1, m}=-\frac{k_{w^{*} \Delta t}}{\rho * \Delta X * \delta X_{w}}, \quad a_{e}{ }^{n+1, m}=-\frac{k_{e} * \Delta t}{\rho * \Delta X * \delta X_{e}} \\
& a_{p}^{n+1, m}=\left(C(T)^{n+1, m}+a_{w}^{n+1, m}+a_{e}^{n+1, m}\right) \\
& R^{n+1, m}=\left(h_{p}^{n}-h_{p}^{n+1, m}+C(T)^{n+1, m} * T_{p}^{n+1, m}\right)
\end{aligned}
$$

The discretized equation (6) can be solved using several numerical schemes [39]. For this study, the equation is solved using the iterative correction scheme developed by Swaminathan and Voller [40]. A direct solver such as Tri-diagonal matrix algorithm (TDMA) can be easily employed to solve $\mathrm{T}^{\mathrm{n}+1, \mathrm{~m}+1}$. Once the temperature field is determined, the node enthalpies are updated based on equation (4). Subsequently, the temperature field is corrected to be in consistent with enthalpy temperature performance curve using the following equation [40]:

$$
T_{p}=\left\{\begin{array}{lrr}
\frac{h_{p}}{C_{s}} & , & h_{p} \leq C_{s} *\left(T_{m}-\epsilon\right) \\
\frac{h_{p}+\left[\frac{C_{l}-C_{s}}{2}+\frac{L}{2 * \epsilon}\right] *\left(T_{m}-\epsilon\right)}{\left[\frac{C_{l}+C_{s}}{2}+\frac{L}{2 * \epsilon}\right]} & , C_{s} *\left(T_{m}-\epsilon\right)< & h_{p}<C_{l} *\left(T_{m}+\epsilon\right)+L \\
\frac{h_{p}-\left(C_{s}-C_{l}\right) * T_{m}-L}{C_{l}} & , & h_{p} \geq C_{l} *\left(T_{m}+\epsilon\right)+L
\end{array}\right.
$$

The iteration process in this prediction-correction cycle continues until convergence is reached. Figure 4 illustrates the calculation procedure adopted in TRNSYS “TYPE285”. 


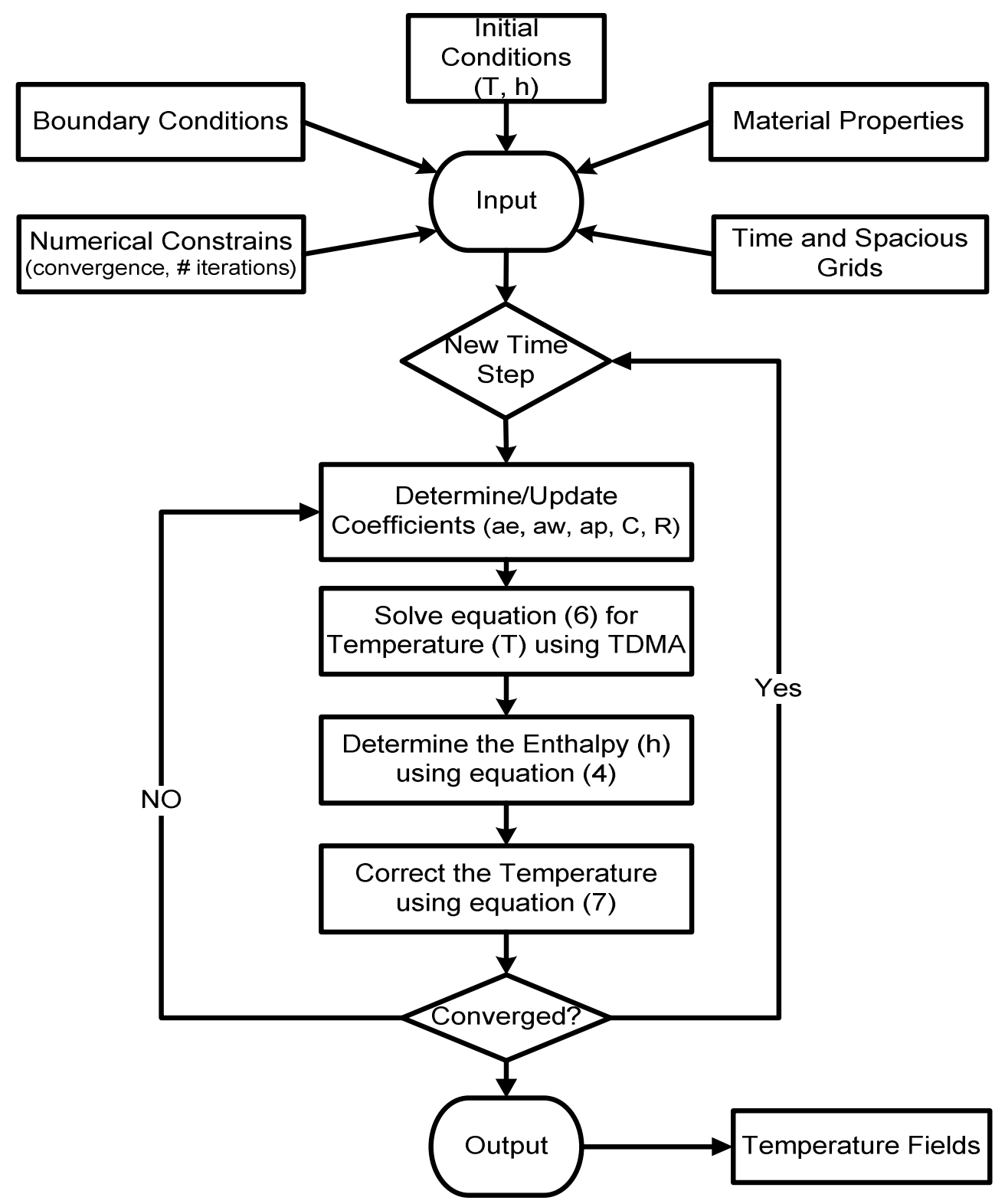

Figure 4 Calculation procedure implemented in TRNSYS “TYPE285”

The developed numerical model is primarily intended for integration into TRNSYS. Hence, a one-dimensional heat transfer equation is selected to reduce the computational time. A fully implicit time stepping scheme is utilized since it is unconditionally stable regardless of the time step. The spatial discretization is based on the finite volume method and the harmonic 
average suggested by Patankar [37] for materials conductivity is used. Although they are important, studies found that hysteresis and sub-cooling are either negligible or less important for common PCMs used in building envelope, hence disregarded in this model [41, 42].

\subsubsection{Model validation}

The numerical model described in this study has been validated at wall level. Since this model is integrated into whole building simulation tool, it is also important to validate the model at building level where complex boundary conditions are considered. Therefore, additional validation for the numerical model at cell level is performed. For this validation, experimental data using two test cells "MICROBAT" from Kuznik's study is used as illustrated in Figure 5 [43].

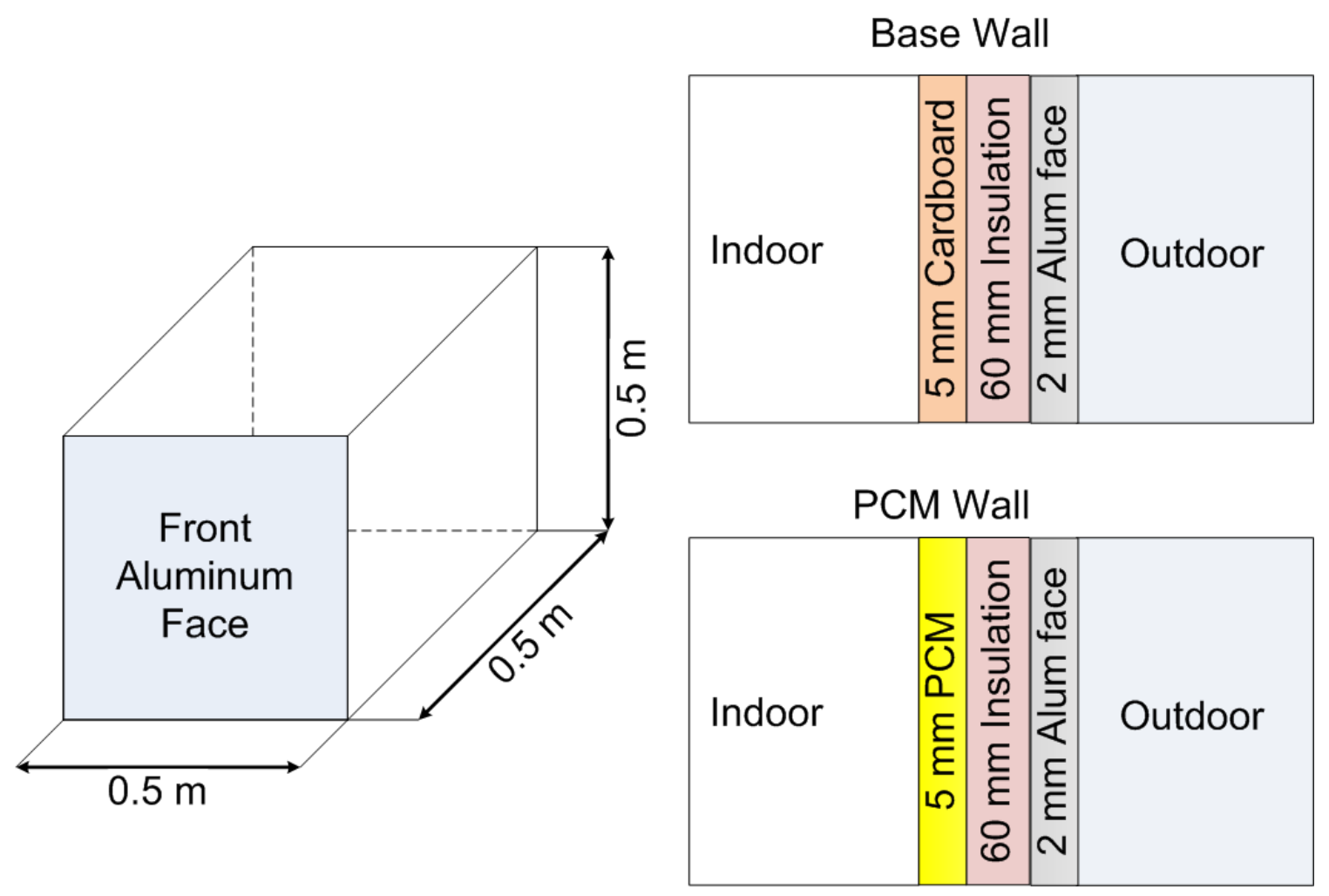

Figure 5 MICROBAT test cells used for validation 
One MICROBAT test cell is without PCM layer for control purpose and the other cell is with PCM layer installed on three vertical walls. The fourth vertical wall is of an aluminum face and all other surfaces are without PCM. The PCM panel used in this experimentation is commercially available [44]. Figure 6 shows the validation results of Type-285 when compared to control test cell and PCM enhanced test cell. The current numerical module Type-285 is also compared to Type-260 developed by Kuznik [43]. Since hysteresis is inherited in this particular PCM product, the melting and freezing curves are both used for comparison. It is clearly obvious that the current model gives reasonable results when compared to experimental data and numerical results predicted by Type- 260 . 
(a) Tind_noPCM_Exp [43] -T_external [43]

-Tind_noPCM_Current_Model

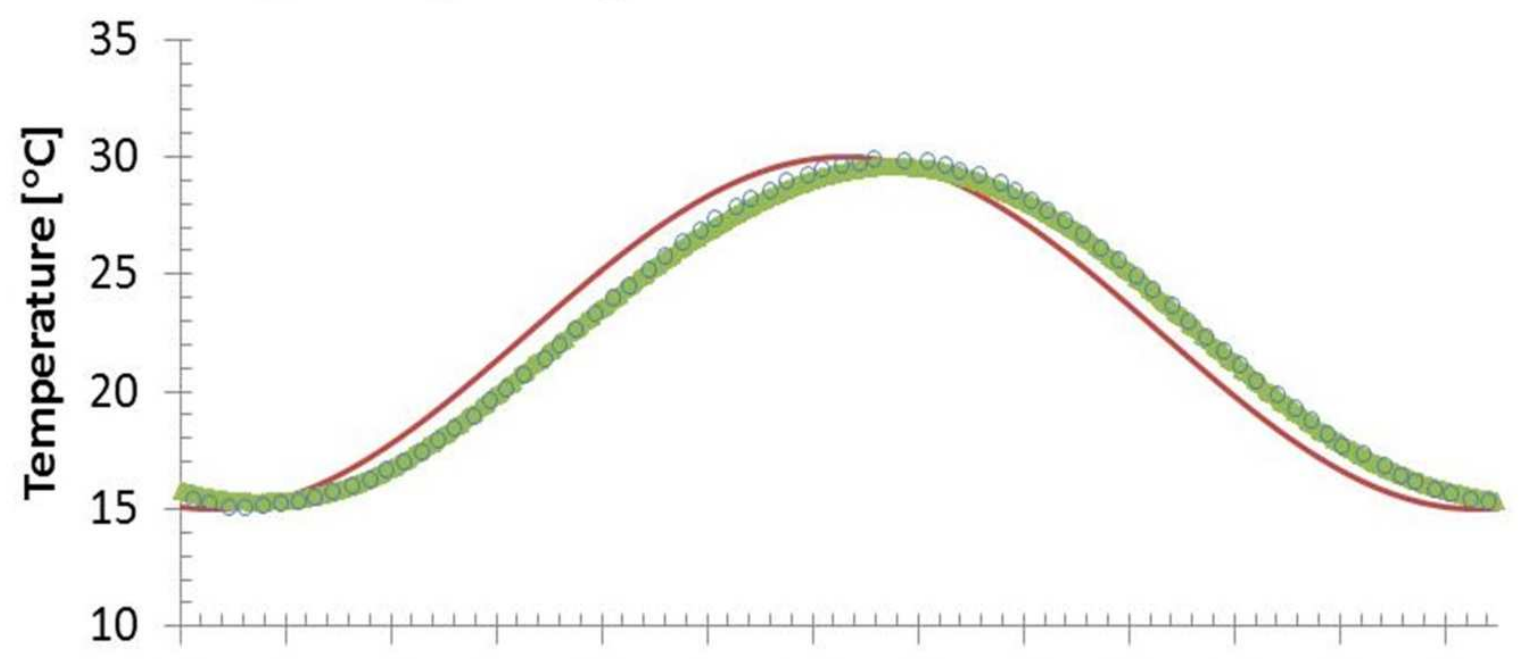

$\begin{array}{lllllllllllll}47 & 49 & 51 & 53 & 55 & 57 & 59 & 61 & 63 & 65 & 67 & 69 & 71\end{array}$ Time [hr]

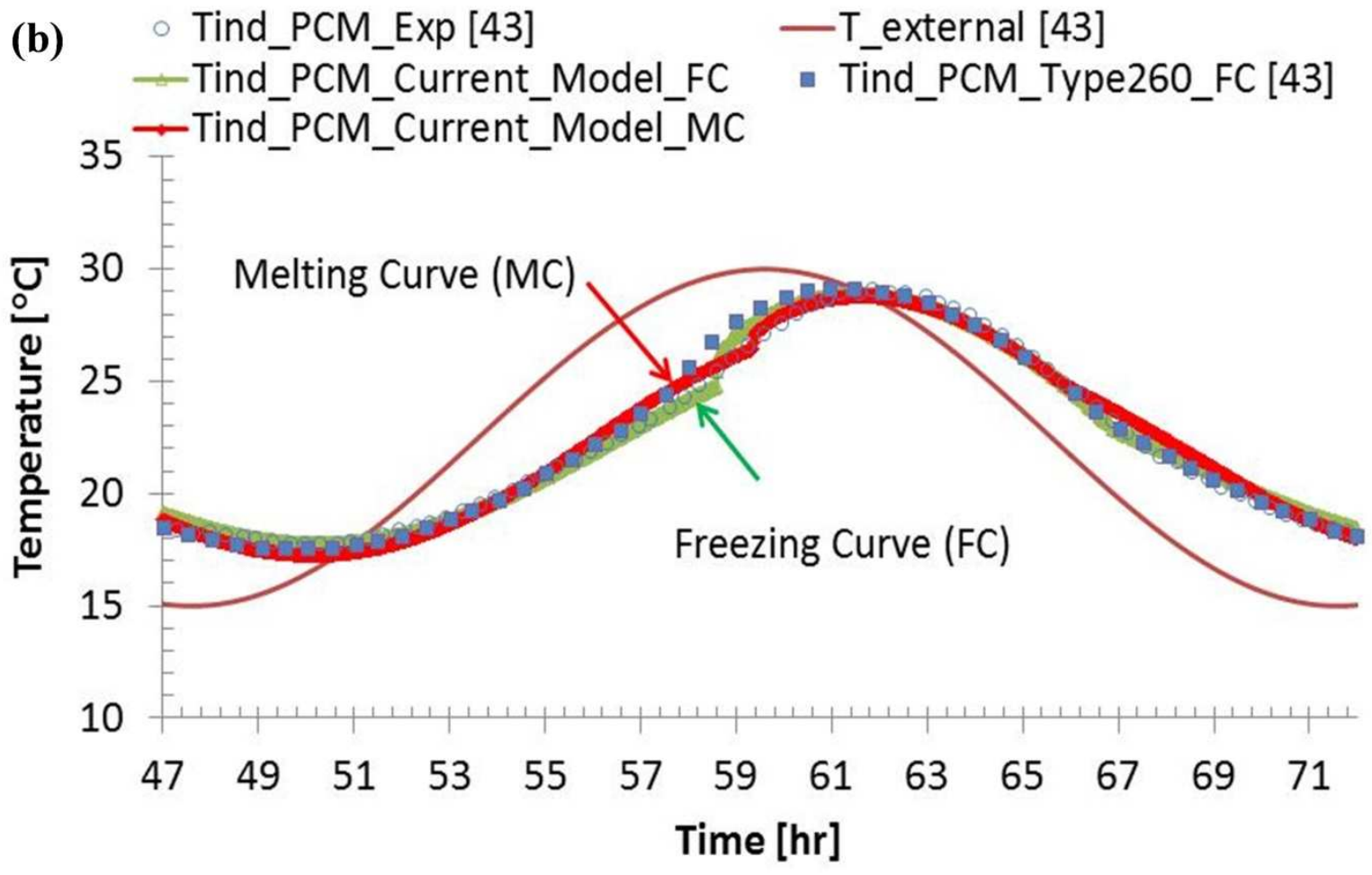

Figure 6 Validation of TRNSYS Type-285 against experimental and numerical results (a) control test cell, (b) PCM-enhanced test cell 


\subsection{The Prototype House model}

Skin-load dominated buildings such as residential types are greatly influenced by the surrounding climatic conditions. Selecting proper envelope designs can significantly reduce the heating and cooling loads, consequently reducing the energy demand. Additionally, this building typology is constructed with poor thermal inertia structure making it ideal candidate for integrating PCM. Therefore, this building typology has been selected to evaluate the thermal performance of PCM-embedded envelope. For this work, Building America House Simulation Protocols published by NREL was the main source used to define a base case residential building [45]. However, other resources have been utilized to set other assumptions too [46, 47].

The building is modeled assuming a single story, detached house. As a simplification, the house is modeled with two thermal zones: main conditioned zone and unconditioned attic zone. The two zones are separated by a highly insulated ceiling assembly as mandated by the local code. The roof slope is assumed to be 4:12 with no overhang, no internal or external shading is assumed. No garage is included in the base case. Based on the highest frequency reported by Kneifel [46] from the U.S. Census' Survey of Construction database, a total floor area of $167 \mathrm{~m}^{2}$ $\left(1800 \mathrm{ft}^{2}\right)$ is considered for this study. To simplify the inputs of internal heat gain in TRNSYS, the schedule and the maximum wattage are determined from the peak consumption load profile and the total electricity consumption estimate [45]. After removing the normalization, the internal heat load profiles used in TRNSYS are shown in Figure 7. To simplify the inputs further, no monthly adjustments as suggested by [45] are performed for the schedules. 


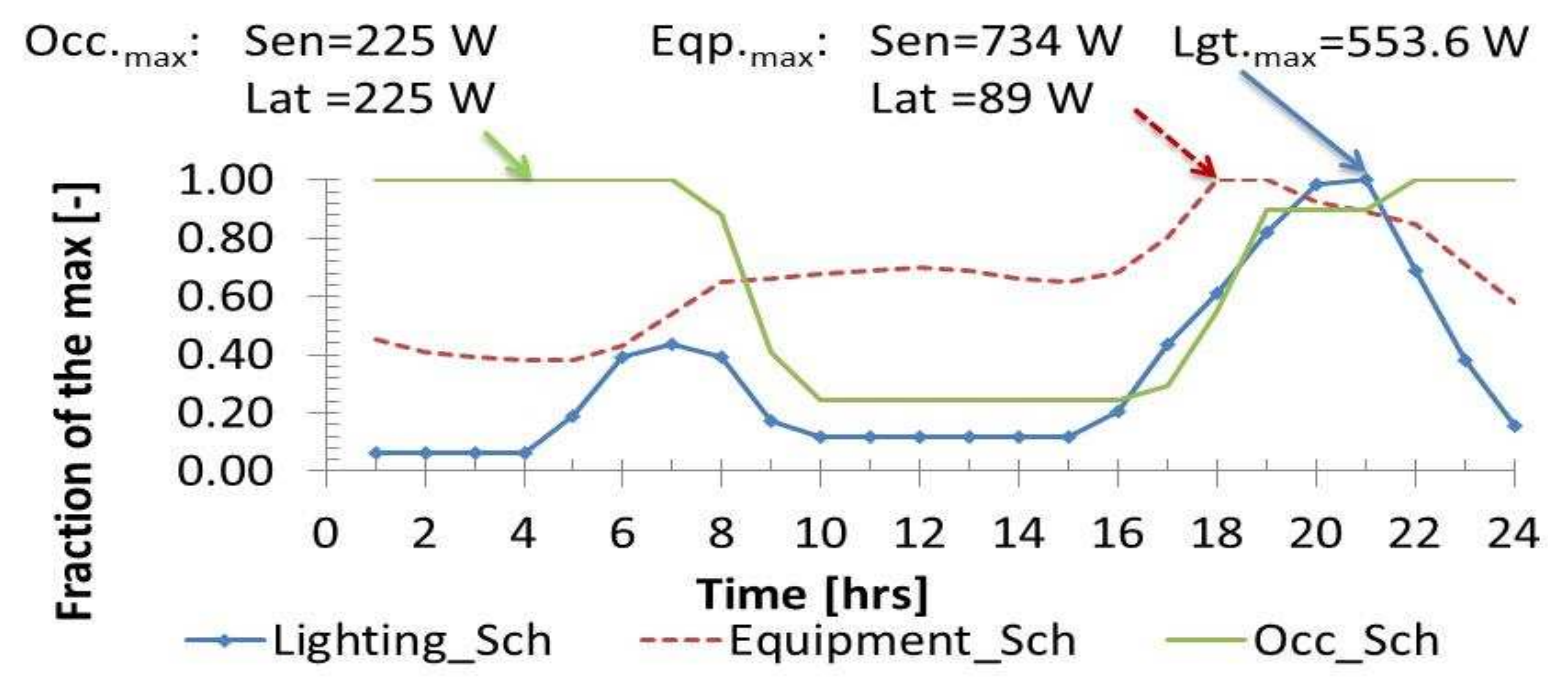

Figure 7 Internal load schedules for the base case residential building

TRNSYS can be used to model HVAC systems in a building at two modeling levels: energy rate control and temperature level control [48]. In this work, the energy rate control modeling approach is adopted to evaluate the impact of PCM on the heating and cooling loads at zone level. This approach assumes simple HVAC system with an ideal control of thermal zones [48]. The energy is added or extracted at the zone level to meet the heating or cooling load as needed to control the indoor air temperature within desirable heating and cooling setpoints. This method is quick, simple and more appropriate for studies that are aimed at zone level evaluation and therefore deemed to be satisfactory for this work. The basic characteristics of the house's model in TRNSYS are summarized in Table 2. For this analysis, four cities representing U.S. climatic zones are selected; Phoenix AZ (Climate Zone-2), Atlanta GA (Climate Zone-3), Seattle WA (Climate Zone-4), and Golden CO (ClimateZone-5). Based on the Building America House Simulation Protocols [45], the base case residential housing has different mandates for different climate zones as shown in Table 3. 
Table 2 Characteristics of the base case model of Residential Building in TRNSYS

\begin{tabular}{|c|c|c|}
\hline Parameter & Description & Remarks \\
\hline Shape/ Dimensions & $\begin{array}{l}\text { One story ( } 3 \text { bedrooms, } 3 \text { baths }) \\
\text { Front of house faces north } \\
\text { Aspect ratio: } 1: 1 \\
\text { Roof slope: } 4: 12 \\
\text { Conditioned Floor Area }=167.29 \mathrm{~m}^{2} \\
\left(1800 \mathrm{ft}^{2}\right) \\
\text { Walls width }=12.93 \mathrm{~m}(42.42 \mathrm{ft}) \\
\text { Floor to Ceiling height }=2.4 \mathrm{~m}(8 \mathrm{ft})\end{array}$ & \\
\hline Modeling Zones & $\begin{array}{l}\text { Two thermal zones: main zone and } \\
\text { attic zone }\end{array}$ & vented attic \\
\hline Foundation & Based on climate zone, refer to Table 3 & \multirow[t]{5}{*}{$\begin{array}{l}\text { As per Building America } \\
\text { benchmark [45] }\end{array}$} \\
\hline Exterior Walls & Based on climate zone, refer to Table 3 & \\
\hline Ceiling R-Value & Based on climate zone, refer to Table 3 & \\
\hline Solar absorptivity & Roof $=0.9$, Wall $=0.6$ & \\
\hline $\begin{array}{l}\text { Window } \\
\text { Area/Distribution }\end{array}$ & $\begin{array}{l}15 \% \text { of exterior wall area, uniformly } \\
\text { distributed in all orientations }\end{array}$ & \\
\hline Window Type & $\begin{array}{l}\text { Double glazing: } \\
\text { Thermal properties are based on climate } \\
\text { zone, refer to Table } 3\end{array}$ & $\begin{array}{l}\text { TRNSYS doesn't use } \\
\text { SHGC but an equivalent } \\
\text { window is selected [47] }\end{array}$ \\
\hline \multirow[t]{2}{*}{ Infiltration Model } & $\begin{array}{l}\text { Room zone: ASHRAE K1,K2, K3 } \\
\text { model }\end{array}$ & \\
\hline & $\begin{array}{l}\text { Attic Zone: } 10 * \text { infiltration of Room } \\
\text { zone }\end{array}$ & As per [47] \\
\hline \multicolumn{3}{|l|}{ Internal Loads } \\
\hline Max lighting power & $\begin{array}{l}553.6 \mathrm{~W} \\
\text { radiative power }=0.4 \\
\text { convective power }=0.6\end{array}$ & \multirow{4}{*}{$\begin{array}{l}\text { As per Building America } \\
\text { benchmark [45] } \\
\text { Refer to Figure } 7 \text { for } \\
\text { internal load schedule }\end{array}$} \\
\hline Max equipment power & $\begin{array}{l}\text { Sensible }=733.3 \mathrm{~W} \\
\text { Latent }=89.3 \mathrm{~W}\end{array}$ & \\
\hline $\begin{array}{l}\text { Max Occupancy load } \\
\text { (3 People) }\end{array}$ & $\begin{array}{l}\text { Sensible }=225 \mathrm{~W} \\
\text { Latent }=225 \mathrm{~W}\end{array}$ & \\
\hline Operation setpoints & $\begin{array}{l}\text { Cooling setpoint }=24^{\circ} \mathrm{C} \\
\text { Heating setpoint }=22^{\circ} \mathrm{C}\end{array}$ & \\
\hline $\begin{array}{l}\text { Weather file } \\
\text { Simulation Time step }\end{array}$ & $\begin{array}{l}\text { TMY3 } \\
5 \text { minutes }\end{array}$ & \\
\hline
\end{tabular}


Table 3 House base case for the four US climates according to Building America benchmark 2010

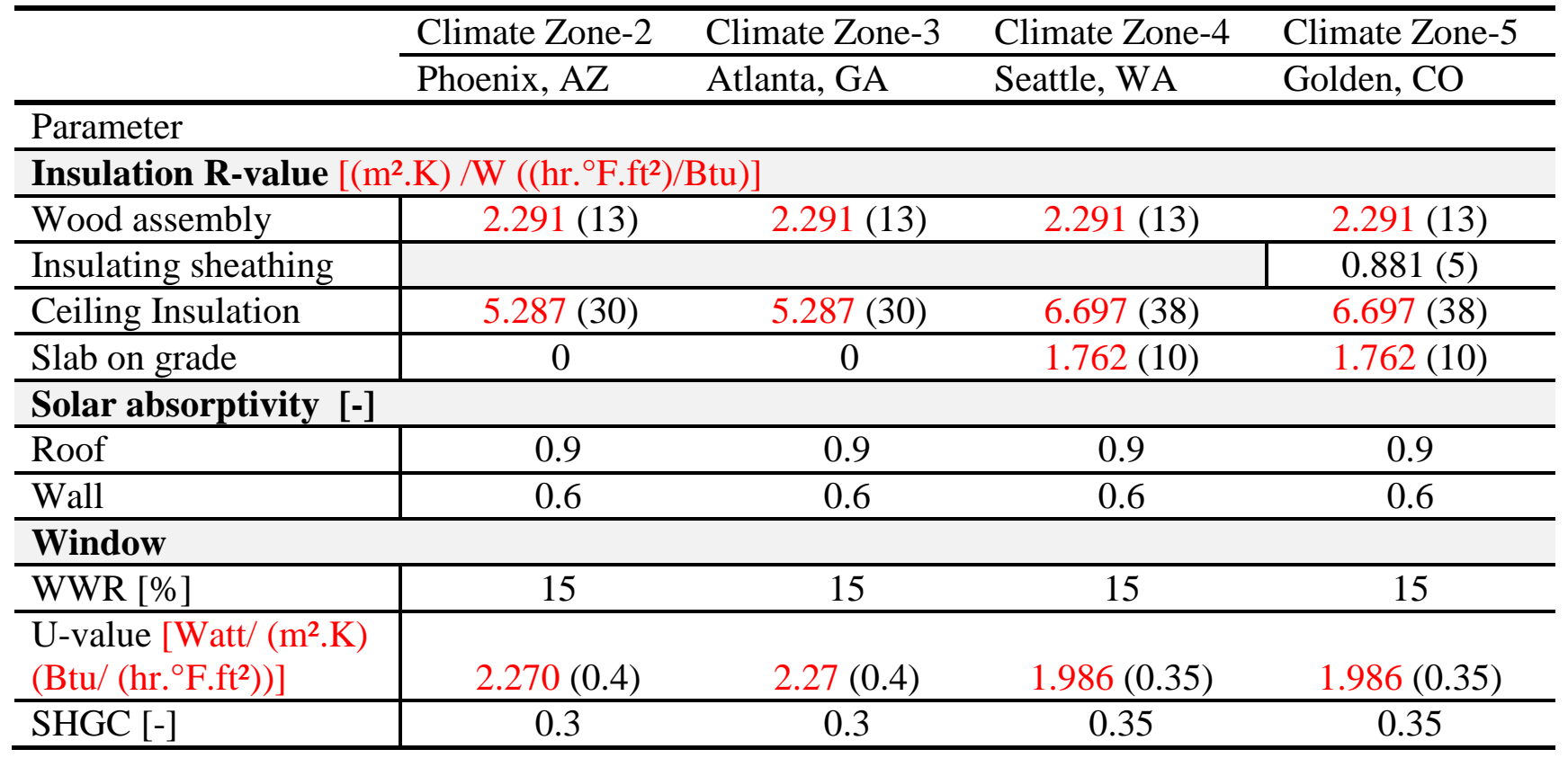

SHGC: solar heat gain coefficient

In TRNSYS, the convective heat transfer coefficient can be assumed a constant or varies if empirical equation is used. For this study case, the internal convective heat transfer coefficient is assumed to be constant at $4.43 \mathrm{~W} / \mathrm{m}^{2} . \mathrm{K}$ based on experimental results from Liu and Awbi for PCM wallboards under natural convection [49]. The outside convective heat transfer coefficient is assumed to be constant at $18 \mathrm{~W} / \mathrm{m}^{2} . \mathrm{K}$ [47]. Palyvos [50] surveyed many correlations and suggested an empirical average correlation for predicting exterior convective heat transfer coefficient for building envelope:

$$
\mathrm{h}_{\mathrm{con}}=7.4+4.0 \mathrm{~V}
$$

The average wind speed from the weather files of the four cities considered in this study was found to vary from 2.7 to $4 \mathrm{~m} / \mathrm{s}$. Using the correlation suggested by Palyvos [50] and the average wind speed, a value between $18-23 \mathrm{~W} / \mathrm{k} \cdot \mathrm{m}^{2}$ for the outside convective heat transfer coefficient is 
determined. Using this correlation, a convective heat transfer coefficient value of $7.4 \mathrm{~W} / \mathrm{k} \cdot \mathrm{m}^{2}$ can be assumed when wind velocity approaches zero. ASHRAE suggests values of 34 and 22 $\mathrm{W} / \mathrm{k} \cdot \mathrm{m}^{2}$ for winter and summer cases respectively when calculating the overall thermal resistance of a wall assembly [51]. Sensitivity study for all four cities with the two extreme values of 7 and $34 \mathrm{~W} / \mathrm{m}^{2} . \mathrm{k}$ indicated that the results reported in this study are within $\pm 0.45 \%$ - $1 \%$ when compared to the base case of $18 \mathrm{~W} / \mathrm{k} \cdot \mathrm{m}^{2}$ which is considered a reasonable assumption. The thermal mass of furniture, contents and internal structural walls should be considered when modeling thermal zones. ASHRAE 90.2 specifies the requirements for the thermal mass [52]. According to ASHRAE 90.2, a value of $3.6 \mathrm{~kg}$ of $5 \mathrm{~cm}$ wood per square foot of conditioned space should be assumed for the furniture. For the structural mass, a value of $2.3 \mathrm{~kg}$ of $1.3 \mathrm{~cm}$ gypsum wall board per square foot of conditioned space is used.

\section{Results and Discussion}

\subsection{Base case modeling results}

Four performance indicators have been selected to investigate the impact of PCM at zonal level: peak heating load, annual heating load, peak cooling load and annual cooling load. Using the indicators, Table 4 provides the results of the base case residential building (no-PCM case) for the four selected climates.

Table 4 Annual loads for the base case house for the four US climates

\begin{tabular}{l|c|c|c|c}
\hline City & $\begin{array}{l}\text { Annual Cooling } \\
\text { Load }[\mathrm{kWh}]\end{array}$ & $\begin{array}{l}\text { Annual Heating } \\
\text { Load }[\mathrm{kWh}]\end{array}$ & $\begin{array}{l}\text { Peak Cooling } \\
\text { Load }[\mathrm{kW}]^{*}\end{array}$ & $\begin{array}{l}\text { Peak Heating } \\
\text { Load }[\mathrm{kW}]^{*}\end{array}$ \\
\hline Phoenix, AZ & 25170 & 143 & 8.14 & 1.71 \\
\hline Atlanta, GA & 5341 & 6468 & 4.59 & 7.37 \\
\hline Seattle, WA & 1044 & 8329 & 3.16 & 4.59 \\
\hline Golden, CO & 2595 & 10130 & 3.50 & 8.49 \\
\hline
\end{tabular}

Notes: * Peak loads are based on TMY3 weather file 
The results of the base cases in this table are used to determine the percentage savings of using PCM-enhanced walls. The percentage savings for each of these indicators will be determined using the following relationship:

$$
\% \text { Savings }=\frac{\text { Load }_{\text {base case }}-\text { Load }_{\mathrm{PCM} \text { case }}}{\text { Load }_{\text {base case }}} * 100
$$

\subsection{Sensitivity analysis of PCM's design determinants}

The thermal behavior of PCMs is highly dynamic when exposed to dynamic environmental conditions. Outside the phase change regime, PCMs behave in a similar fashion to other sensible materials. The design determinants are based on many factors such as PCMs location in the wall, wall orientation, solar radiation, internal gains, color of the surface, natural ventilation rate, latent heat, melting temperature, and melting range [53]. For this study, the parameters vary include: 1) location of the PCM in the wall, 2) wall orientations, and 3) PCM's thermal properties: latent heat of fusion, melting temperature, and melting temperature range. For this analysis, the climate of Golden, Colorado is selected.

\subsubsection{PCM location within the wall assembly}

The external wall in the base case is modified by placing a PCM layer with a $12.5 \mathrm{~mm}$ thickness at three locations: to the interior side (iPCM), in the middle of the wood assembly (midPCM), and to the exterior side of the wall (ePCM) as shown in Figure 8. A PCM layer with a latent heat of $200 \mathrm{~kJ} / \mathrm{kg}$ is selected with varying melting temperature and melting range. For this design case, the annual cooling and heating loads are selected as performance indicators. 


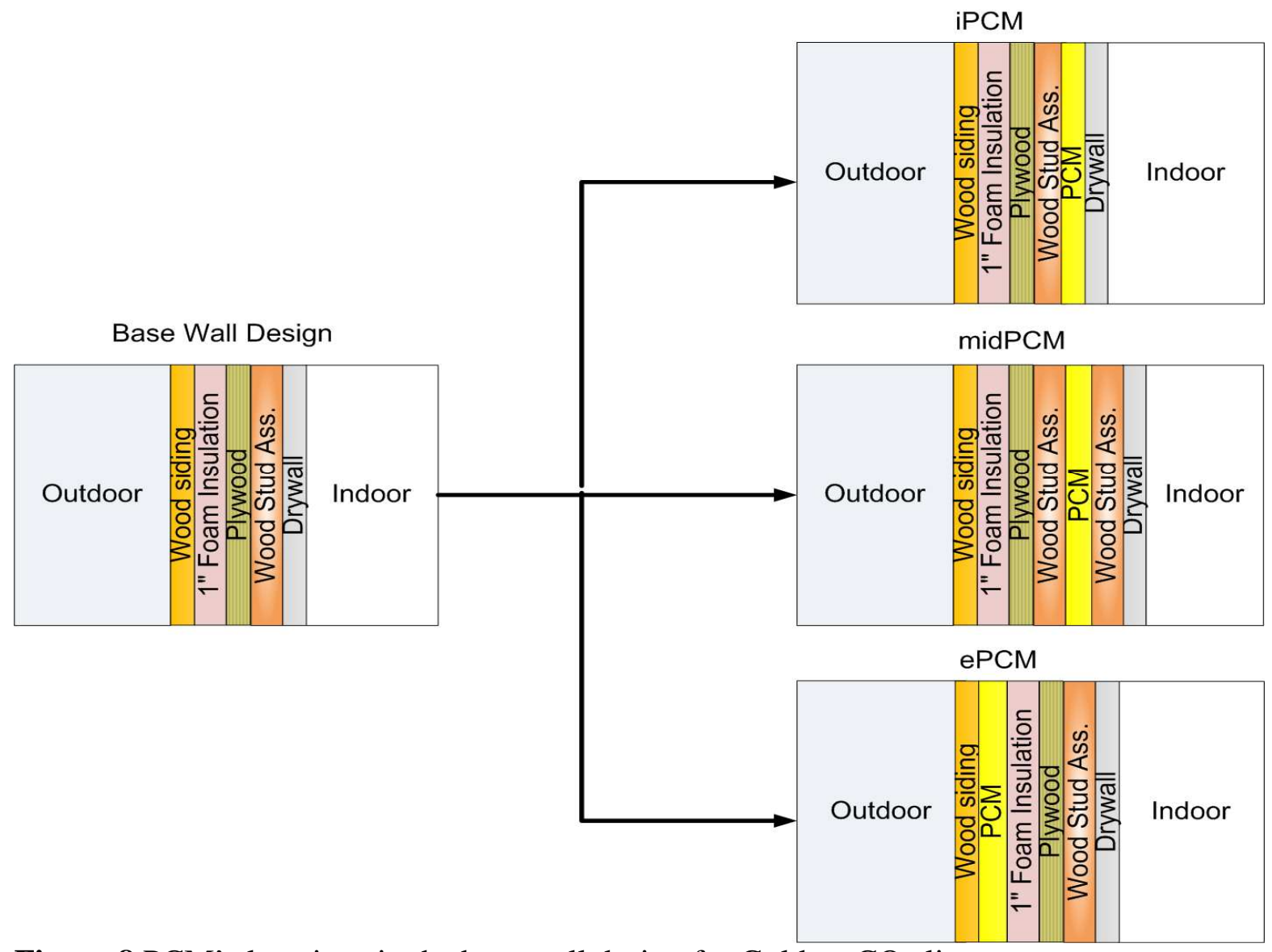

Figure 8 PCM's locations in the base wall design for Golden, CO climate

Figure 9 shows the impact of locating the PCM on the annual zonal loads. When PCM is located to the interior side, maximum cooling savings of $6 \%$ occurs at $1^{\circ} \mathrm{C}$ below the cooling setpoint with $1^{\circ} \mathrm{C}$ melting temperature range being the best. The savings in annual heating loads is $2.4 \%$ and occurs at the heating setpoint with a $2^{\circ} \mathrm{C}$ melting temperature range. As the PCM location moves away from the indoor environment, the savings becomes less significant. The lowest savings are observed when the PCM is located on the exterior side. For the PCM to the middle, the savings in cooling load drops by almost half and optimal properties moves to the wide melting range side of $4^{\circ} \mathrm{C}$. The maximum savings in annual heating load is in the range of $1.8 \%$ which is not significantly different than the iPCM case but the melting range covers wider 
melting range region $\left(2-8^{\circ} \mathrm{C}\right)$ at optimal melting temperature of $20^{\circ} \mathrm{C}$ as depicted in Figure 9 (b). When PCM layer is located to the exterior side, the optimal melting temperature for maximum savings in cooling and heating loads is shifted to the cold range. This is an expected result for the cold climate of Colorado.
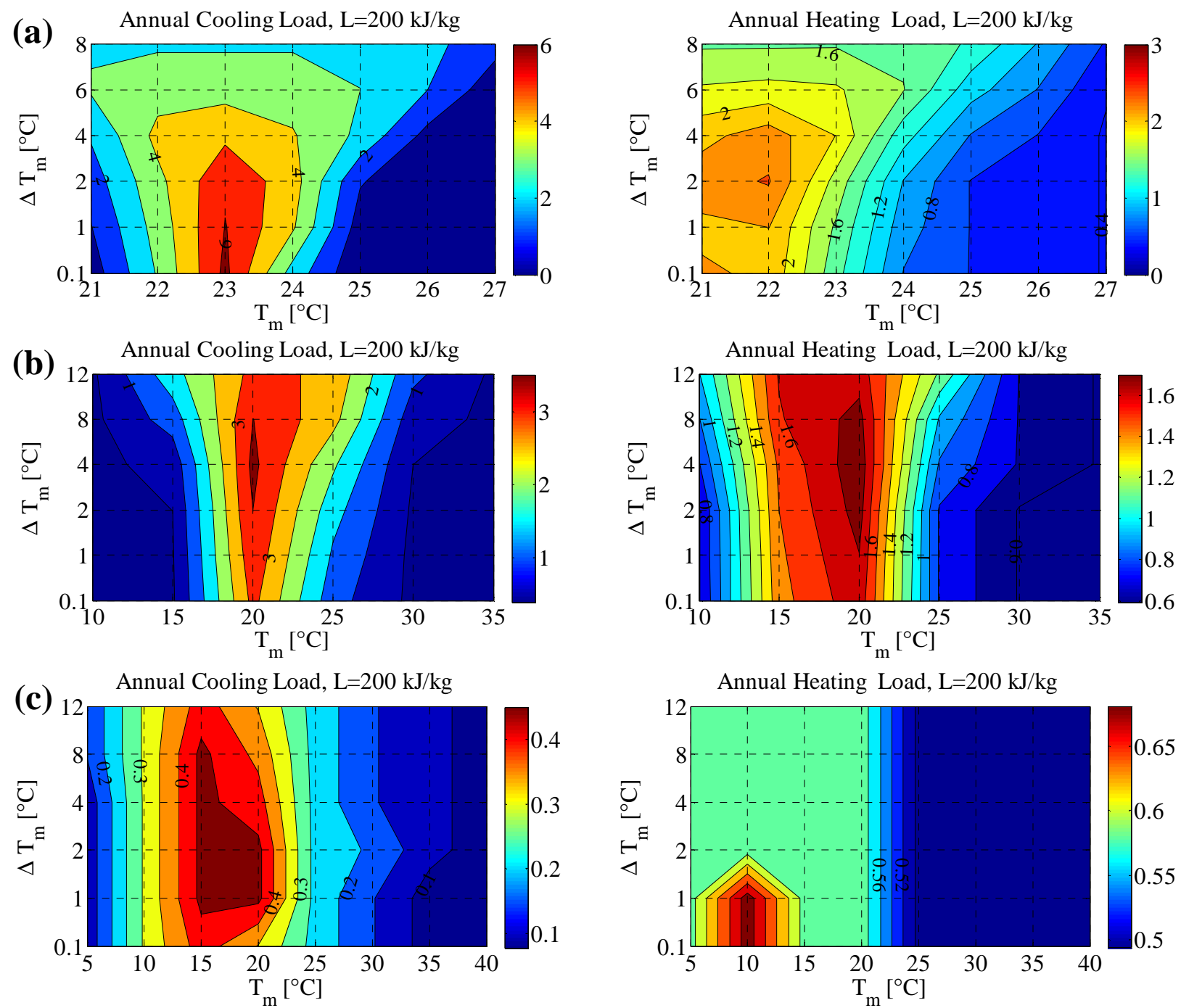

Figure 9 Percentage savings in annual cooling and heating loads for the case of $200 \mathrm{~kJ} / \mathrm{kg}$ under Golden, CO when (a) PCM located to the interior side (iPCM case), (b) PCM located in the middle (midPCM case) and (c) PCM located to the exterior side (ePCM case)

\subsubsection{PCM's thermal performance at different orientations}

The previous section considers the use of PCM layer equally in all orientations at different locations within the wall assembly. The best PCM location was found to the interior 
side of the wall. Therefore, the iPCM case (i.e., PCM to the interior side) is selected to study the impact of PCM on individual orientation on annual loads. The latent heat case of $200 \mathrm{~kJ} / \mathrm{kg}$ is selected with a melting temperature ranges from $22-23^{\circ} \mathrm{C}$ and melting range $1-2^{\circ} \mathrm{C}$. This range provides maximum savings in annual heating and cooling load as shown previously in Figure 9 (a). The result of every orientation is shown in Table 5. Although the savings in annual loads for using PCM at specific orientation are insignificant, the table shows that the maximum savings are achieved in south, west and east, and finally north. When PCM is utilized in all orientations, the savings for both annual cooling and heating loads are manifested.

Table 5 Impact of interior PCM on annual loads when placed at different orientations for Golden, $\mathrm{CO}$

\begin{tabular}{l|cccc}
\hline Orientation & $\mathrm{T}_{\mathrm{m}}\left[{ }^{\circ} \mathrm{C}\right]$ & $\Delta \mathrm{T}_{\mathrm{m}}\left[{ }^{\circ} \mathrm{C}\right]$ & $\begin{array}{c}\text { Annual heating load } \\
\text { reduction [\%] }\end{array}$ & $\begin{array}{c}\text { Annual cooling load } \\
\text { reduction [\%] }\end{array}$ \\
\hline \multirow{2}{*}{ East Wall } & 22 & $1-2$ & $0.62-0.65$ & $1.03-1.14$ \\
& 23 & $1-2$ & $0.50-0.52$ & $1.77-1.80$ \\
\hline \multirow{2}{*}{ South Wall } & 22 & $1-2$ & $0.68-0.74$ & $0.96-1.07$ \\
\cline { 2 - 5 } & 23 & $1-2$ & $0.55-0.59$ & $1.69-1.84$ \\
\hline \multirow{2}{*}{ West Wall } & 22 & $1-2$ & $0.67-0.74$ & $0.99-1.07$ \\
\cline { 2 - 5 } & 23 & $1-2$ & $0.53-0.58$ & $1.58-1.69$ \\
\hline \multirow{2}{*}{ North Wall Walls } & 22 & $1-2$ & $0.62-0.67$ & $0.99-1.10$ \\
\cline { 2 - 5 } & 23 & $1-2$ & $0.48-0.52$ & $1.55-1.66$ \\
\hline & 22 & $1-2$ & $2.20-2.42$ & $3.43-3.74$ \\
\hline
\end{tabular}

\subsubsection{Simulation of a PCM case under other climates}

Many studies including this one suggested that the best PCM location is when it is placed into direct contact with indoor environment [54-58]. Hence, all walls in the base case house are placed with PCM to the interior side. Wide PCM's melting temperatures and melting range are studied where a latent heat of $200 \mathrm{~kJ} / \mathrm{kg}$ is selected for all climates under study. Figure 10 shows the savings in annual cooling and heating loads for this latent heat case. Regardless of climate, 
the figure indicates a similar trend of optimal melting temperatures and melting range. For maximum savings in annual cooling loads, the optimal melting temperature is $23^{\circ} \mathrm{C}$, a degree below the cooling setpoint of $24^{\circ} \mathrm{C}$. For maximum savings in heating loads, the optimal melting temperature is at the heating setpoint of $22^{\circ} \mathrm{C}$.

The PCM layer performs better when the melting range is at a narrow melting range (i.e., $0.1-1^{\circ} \mathrm{C}$ ) for maximum savings in annual cooling loads. The maximum percentage savings in annual cooling loads are achieved in Seattle (13\%), Golden (6\%), Atlanta (2.2\%) and finally Phoenix (0.6\%). Although insignificant, an interesting observation for Phoenix is that the PCM would increase the annual cooling loads when its melting temperature is $25^{\circ} \mathrm{C}$ and a narrow melting range of $0.1^{\circ} \mathrm{C}$ is used. For maximum savings in annual heating loads, a wide melting range of $2^{\circ} \mathrm{C}$ is favorable across all climates. The percentage savings in annual heating loads for Golden, Atlanta and Seattle ranges from 2.4\% to 3.8\%. Since the annual heating load for Phoenix is insignificant for the base case, refer to Table 4, the relative saving is significant when compared to the small base case value. 


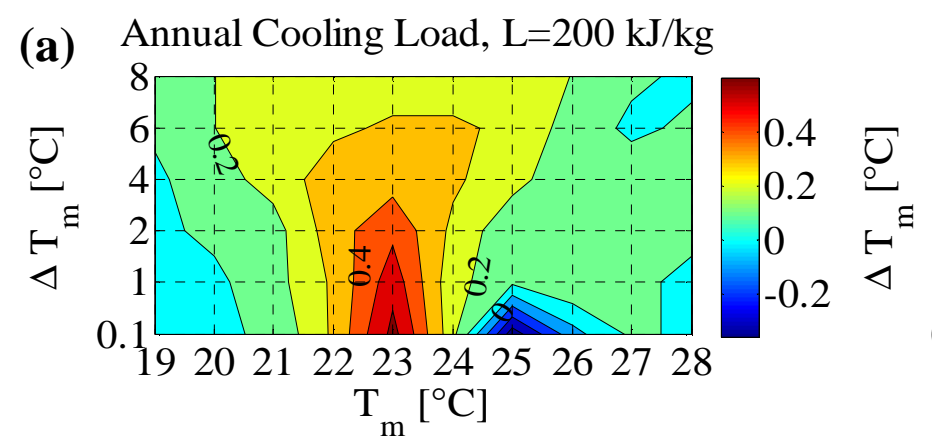

Annual Heating Load, L=200 kJ/kg

(b) Annual Cooling Load, L=200 kJ/kg

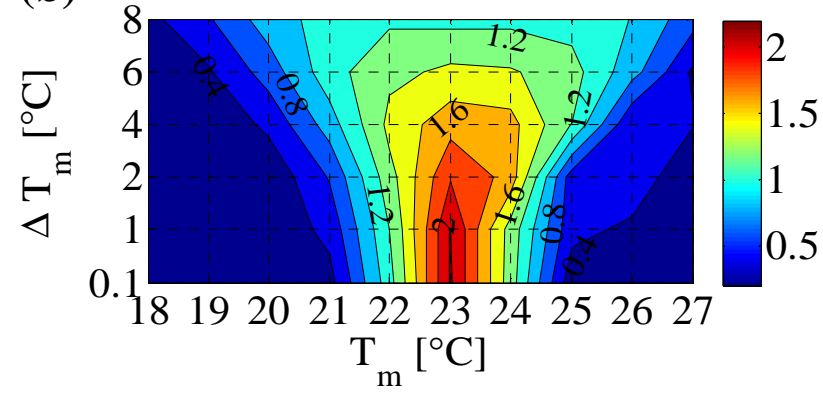

(c) Annual Cooling Load, L=200 kJ/kg

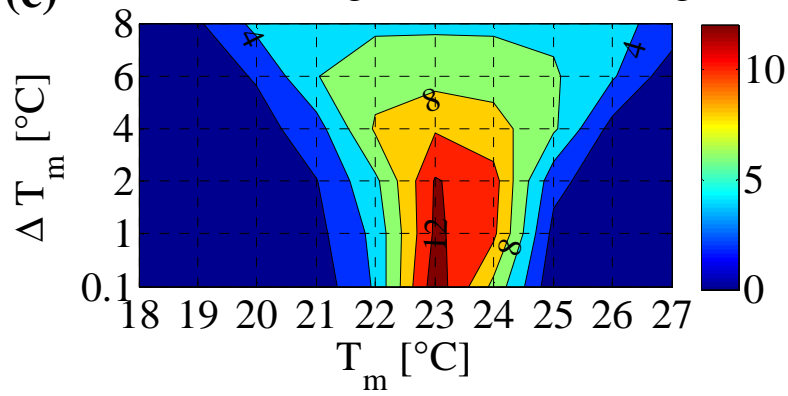

(d) Annual Cooling Load, L=200 kJ/kg
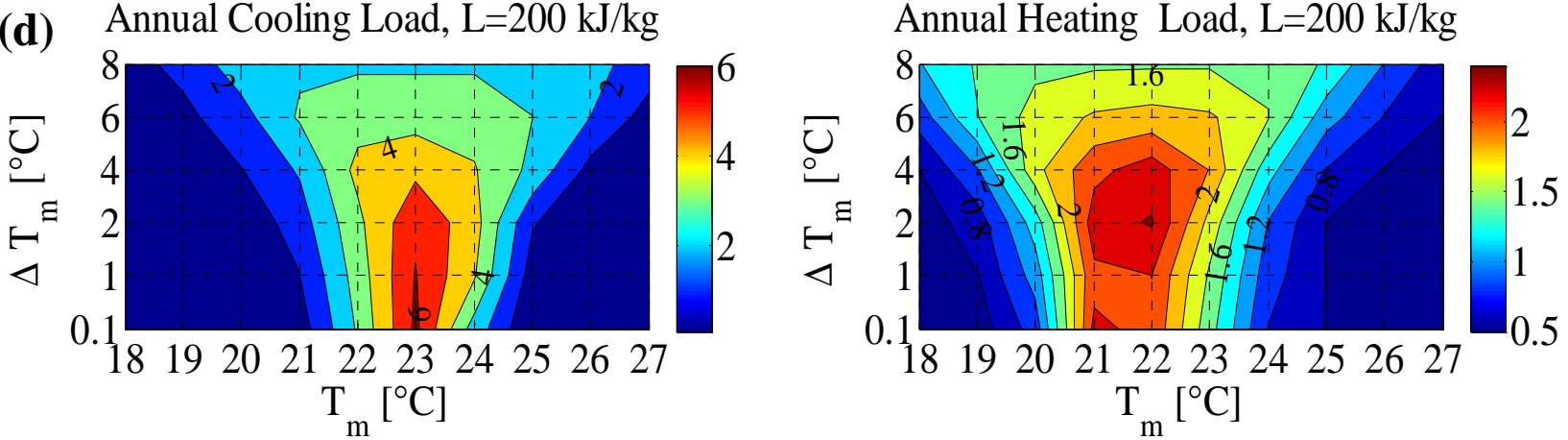

Figure 10 Percentage savings in annual cooling and heating loads due to PCM (a) Phoenix AZ, (b) Atlanta GA, (c) Seattle WA and (d) Golden CO

Another advantage of using PCM is the ability to reduce the peak loads. Figure 11 illustrates the percentage savings in peak cooling and heating loads for the four cities. Since the 
peak loads occur at extreme conditions, the maximum savings in peak loads also occur at higher or lower conditions than those experienced for annual loads. The maximum percentage savings in peak cooling loads are achieved in Atlanta (11\%), Seattle (9.5\%), Golden (9\%), and finally Phoenix (6.6\%). As observed from the figure, the maximum savings in peak cooling loads occur at optimal melting temperature of $25^{\circ} \mathrm{C}$ for Atlanta, Seattle, and Golden and at $26^{\circ} \mathrm{C}$ for Phoenix. The optimal melting temperature values are $3{ }^{\circ} \mathrm{C}$ higher in Phoenix and $2^{\circ} \mathrm{C}$ higher in the other three climates than those found for maximum savings in annual cooling load. The melting temperature range lies between $0.1-1^{\circ} \mathrm{C}$ for Atlanta, Golden and Phoenix where Seattle favors 1$2^{\circ} \mathrm{C}$ melting range.

The percentage savings in peak heating loads for Seattle, Atlanta and Golden are 8.5\%, $5.3 \%$ and $4.1 \%$ respectively. Similar to the savings in annual heating loads, the savings in peak heating loads for Phoenix is as high as $23 \%$. These savings occur at a melting temperature of $19^{\circ} \mathrm{C}$ in Atlanta and Golden, $20^{\circ} \mathrm{C}$ in Seattle and $21^{\circ} \mathrm{C}$ in Phoenix where a narrow melting range of $0.1-1^{\circ} \mathrm{C}$ is favorable across all climates. These optimal melting temperature values are $1^{\circ} \mathrm{C}$ lower than those found for maximum savings in annual heating loads. 
(a) Peak Cooling Load, L=200 kJ/kg

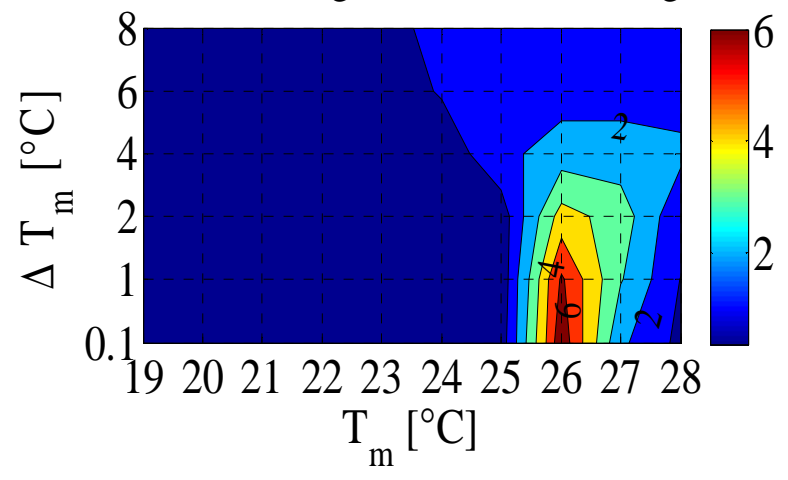

(b) Peak Cooling Load, L=200 kJ/kg

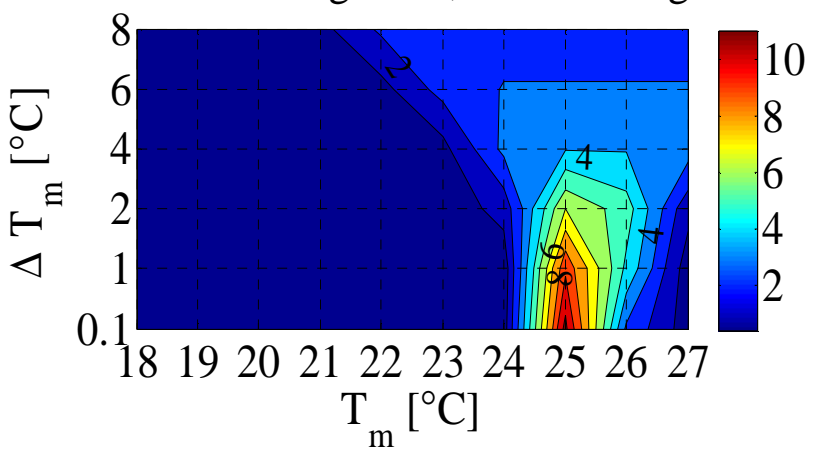

(c) Peak Cooling Load, L=200 kJ/kg

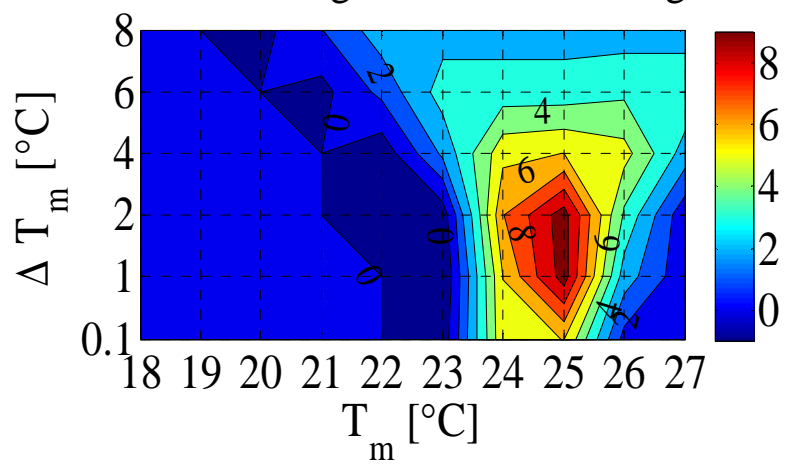

(d) Peak Cooling Load, L=200 kJ/kg

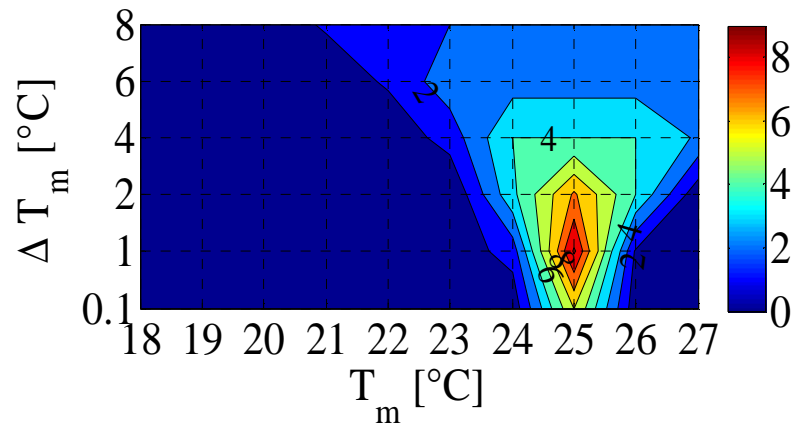

Peak Heating Load, L=200 kJ/kg

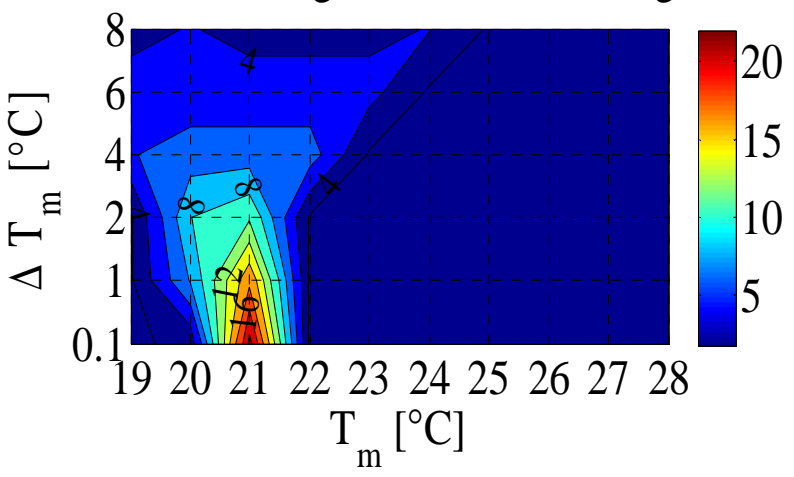

Peak Heating Load, L=200 kJ/kg

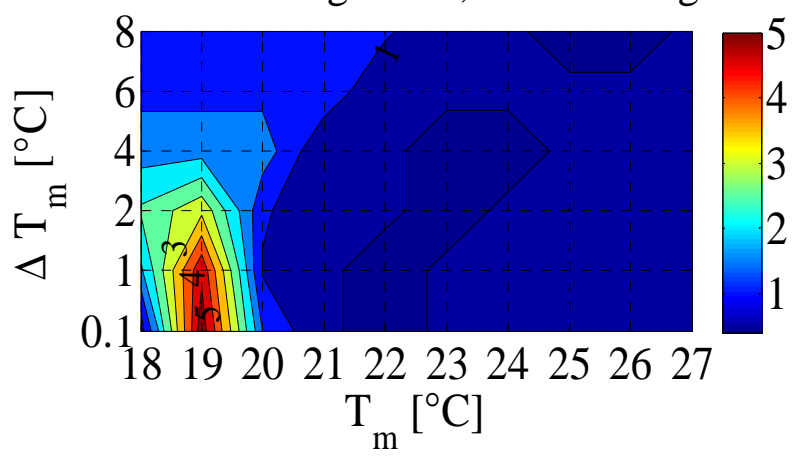

Peak Heating Load, L=200 kJ/kg

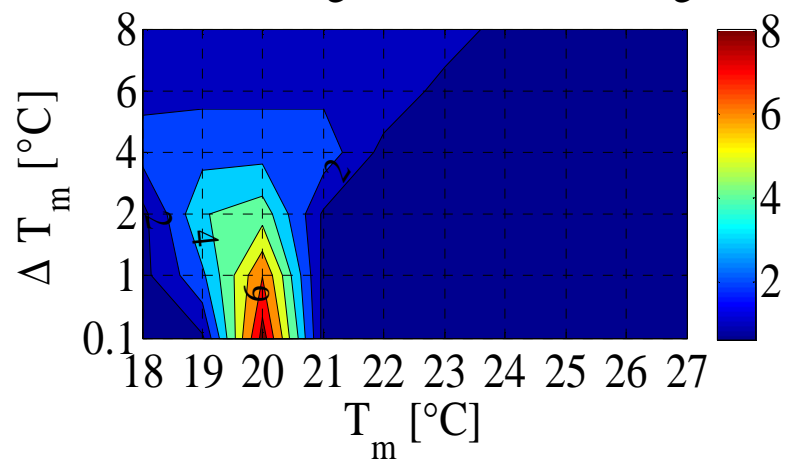

Peak Heating Load, L=200 kJ/kg

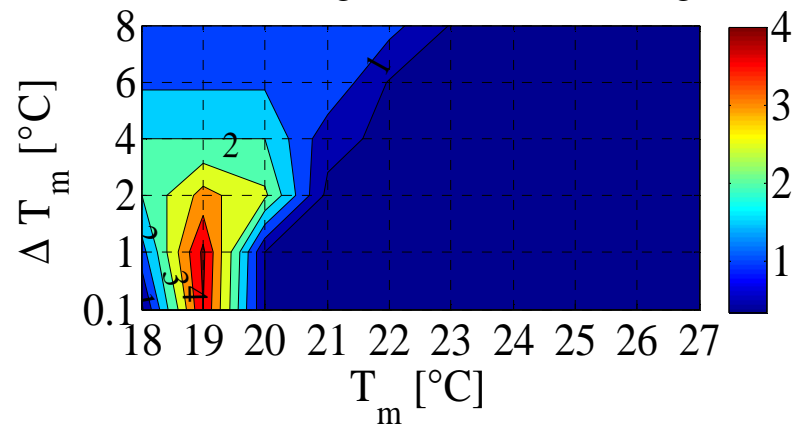


Figure 11 Percentage savings in peak loads due to PCM (a) Phoenix AZ, (b) Atlanta GA, (c) Seattle WA and (d) Golden CO

\subsection{Simulation of other latent heat cases of $50-300 \mathrm{~kJ} / \mathrm{kg}$}

Other cases of latent heat cases were also simulated to identify the optimal melting temperature and melting range across the different latent heat cases for different climates. The latent heat cases of $50-300 \mathrm{~kJ} / \mathrm{kg}$ on 50 increments and a melting temperature range between 0.1 $8^{\circ} \mathrm{C}$ were selected. For Phoenix climate, the melting temperature was varied from $19-28^{\circ} \mathrm{C}$ on $1^{\circ} \mathrm{C}$ increment to capture the effect of hot climate on PCM performance. For the remaining three climates, the PCM layer was selected with melting temperature between $18-27^{\circ} \mathrm{C}$ on $1{ }^{\circ} \mathrm{C}$ increment. A total of 360 yearly simulation runs for each climate were performed. In order to simplify the analysis, the maximum savings in annual and peak loads for every latent heat case are extracted with their corresponding optimal melting temperature and melting range from the simulation results as summarized in Table 6 and Table 7.

Generally speaking, the optimal melting temperature for maximum savings in annual heating loads is at the heating setpoint of $22^{\circ} \mathrm{C}$ as shown in Table 6. There are cases where the optimal melting temperature is $1^{\circ} \mathrm{C}$ below the heating setpoint especially in Phoenix (a case of $50 \mathrm{~kJ} / \mathrm{kg}$ ) and in Seattle (cases of 50 and $100 \mathrm{~kJ} / \mathrm{kg}$ ). It is observed that finding a universal optimal melting range for PCM is challenging. To achieve maximum savings in annual heating loads, a melting range temperature greater than $1^{\circ} \mathrm{C}$ is necessary. Atlanta is an exception where the maximum savings in annual heating loads occur at melting range of $0.1^{\circ} \mathrm{C}$. As clear from the table, the maximum reductions in annual heating load across the latent heat cases are 22.655.8\%, 2-4.2\%, 1.9-3.6\%, 1.3-2.8\% for Phoenix, Atlanta, Seattle, and Golden, respectively. 
Across the four climates, the maximum savings in annual cooling loads occur at an optimal melting temperature of $23^{\circ} \mathrm{C}$ (i.e., $1^{\circ} \mathrm{C}$ below the cooling setpoint of $24^{\circ} \mathrm{C}$ ). Together with proper melting temperature, a melting range of $0.1-1^{\circ} \mathrm{C}$ will achieve maximum savings in annual cooling load. However, Golden climate favors a melting range between $1-2^{\circ} \mathrm{C}$ depending on the latent heat. According to Table 6, the maximum reductions in annual cooling load across the latent heat cases are $0.2-0.8 \%, 0.8-2.6 \%, 3.6-15.8 \%, 1.5-7.3 \%$ for Phoenix, Atlanta, Seattle, and Golden, respectively. 


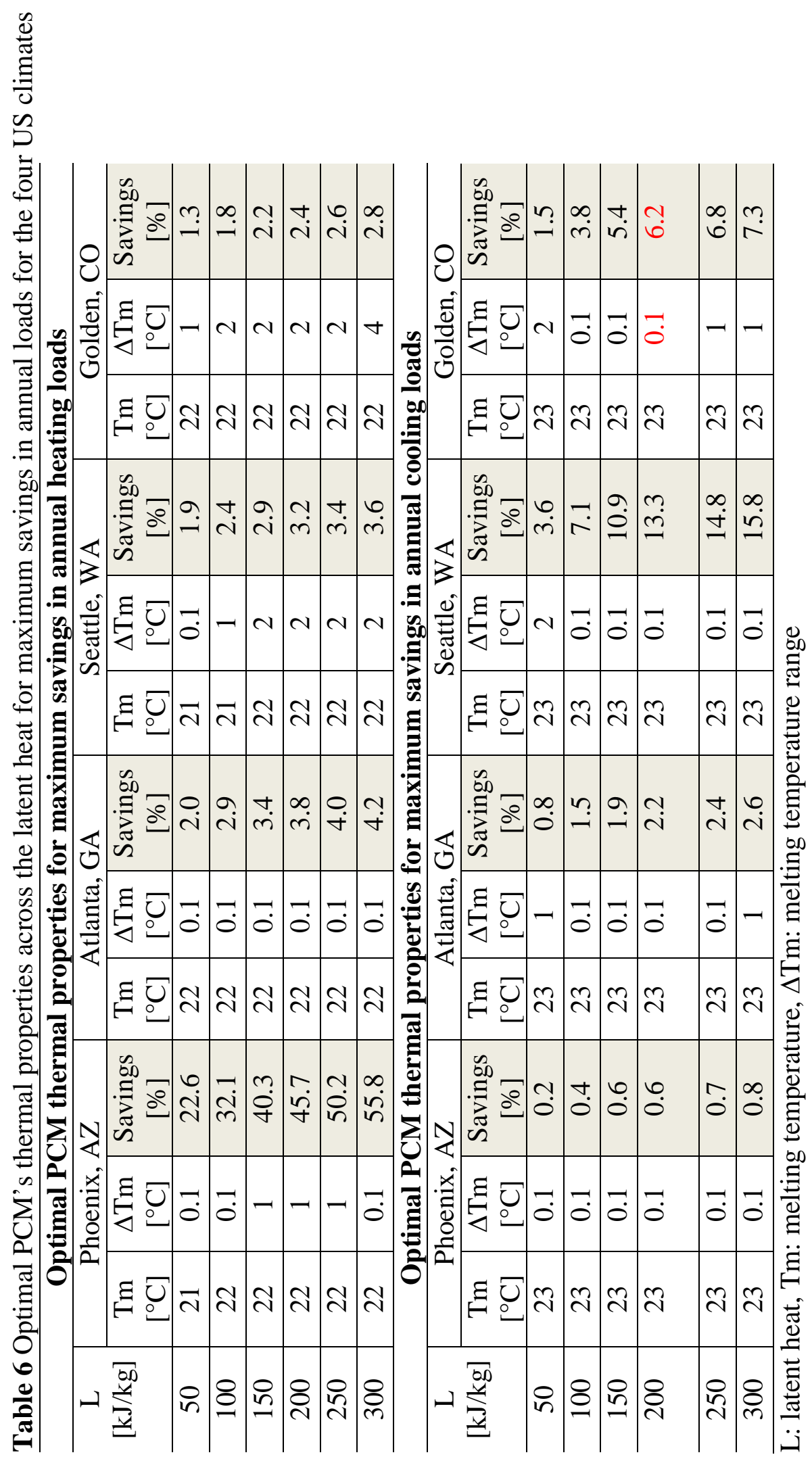


In addition to the annual load, peak load is another performance indicator that is of a particular interest when thermal storage is utilized in buildings. Table 7 summarizes the maximum percentage savings in both peak cooling and heating loads for the four US cities. The optimal melting temperature for maximum savings in peak cooling load occurs at a degree higher than the cooling setpoint of $24^{\circ} \mathrm{C}$ for the climates of Atlanta, Golden and Seattle, but a two degree above the cooling setpoint is observed for the hot climate of Phoenix as shown in Table 7. However, there are some exceptional extreme cases that show different optimal melting temperature than the generalized trend. For example, the case of $300 \mathrm{~kJ} / \mathrm{kg}$ under Seattle climate shows an optimal melting temperature of $24^{\circ} \mathrm{C}$ and the case of $50 \mathrm{~kJ} / \mathrm{kg}$ shows an optimal temperature of $26^{\circ} \mathrm{C}$ and $27^{\circ} \mathrm{C}$ for Atlanta and Phoenix, respectively. For Atlanta and Phoenix, a melting range of $0.1-1{ }^{\circ} \mathrm{C}$ is preferable compared to a melting range of $0.1-2^{\circ} \mathrm{C}$ for Golden and Seattle climates. The maximum savings in peak cooling load for the latent heat cases of 50$300 \mathrm{~kJ} / \mathrm{kg}$ are $1.6-6.8 \%, 2.8-11.3 \%, 4.4-13.3 \%$ and $5.4-10.3 \%$ for Phoenix, Atlanta, Seattle, and Golden respectively. On the other hand, the optimal melting temperature for maximum reductions in peak heating load occurs at $20-21^{\circ} \mathrm{C}$ depending on latent heat for Phoenix as summarized in Table 7. According to the summarized results in the table, the other three climates favor a degree lower in melting temperature than Phoenix (i.e., 19-20 ${ }^{\circ} \mathrm{C}$ ). The maximum reductions in peak heating load for latent heat cases $50-300 \mathrm{~kJ} / \mathrm{kg}$ are $4.7-23.4 \%, 2.3-$ 10.5\%, 1.7-8.9\% and 2.6-7\%, for Phoenix, Atlanta, Seattle, and Golden, respectively. For all climates, there is a limited benefit for reducing peak loads by increasing the latent heat beyond $150 \mathrm{~kJ} / \mathrm{kg}$. 


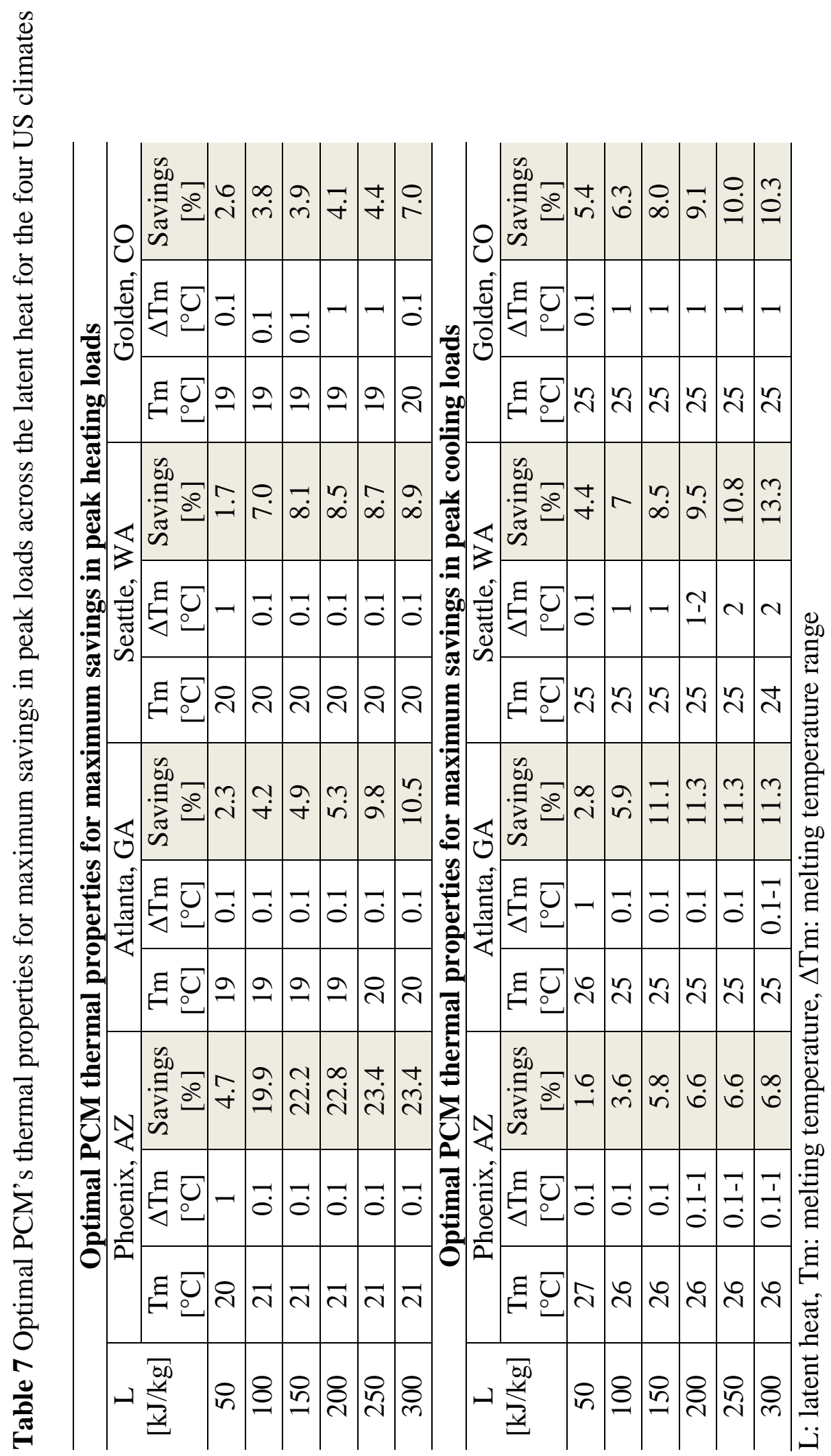




\subsection{Summary of results}

Several hundred simulation runs were performed and the results are further summarized in Table-8. For maximum savings in annual heating load, the optimal melting temperature should either be at a heating setpoint of $22^{\circ} \mathrm{C}$ or one degree lower depending on PCM's latent heat. A narrow melting range of $0.1-2^{\circ} \mathrm{C}$ is favorable with exception of Golden which demands $1-4^{\circ} \mathrm{C}$ melting range. In the heating dominated climate, the savings in annual heating loads are insignificant; a maximum of $4 \%$ is achieved in Atlanta. For maximum savings in annual cooling load, the optimal melting temperature is a degree lower than the cooling setpoint across all climates. The corresponding melting temperature goes from a very tight value of $0.1^{\circ} \mathrm{C}$ in a severe summer climate to a little wider melting range of $2^{\circ} \mathrm{C}$ in mild summer climates. The maximum savings in annual cooling load ranges from $0.8-15.8 \%$ where the lower value is in cooling dominated climate of Phoenix and the higher value for the mild summer climate of Seattle.

Unlike the savings in annual loads, the peak loads show a higher potential for some climates but at different optimal PCM's thermal properties. This demands a careful selection of PCM's thermal properties by designers depending on the overall design objective. Apart from Phoenix which calls for low heating demand, the maximum savings in peak heating load ranges from $7-10.5 \%$ in heating dominated climates. The melting temperature is $1-3^{\circ} \mathrm{C}$ below the heating setpoint depending on the latent heat and climate with a melting range of $0.1-1^{\circ} \mathrm{C}$. The maximum savings in peak cooling load are $6.8-13.3 \%$ where the lower value is achieved in Phoenix and the higher value is achieved in Seattle. To achieve these values, the melting temperature should generally be between $24-26^{\circ} \mathrm{C}$ for mild summer climate and $26-27^{\circ} \mathrm{C}$ for 
cooling dominated climate with a melting range should be in the range of $0.1-2^{\circ} \mathrm{C}$ depending on climate.

For benchmark comparison, the results in Table-8 can be compared to those summarized in Table 1. Medina and co-workers reported an average reduction of $9-11 \%$ in space cooling and a reduction of $5.7-15 \%$ in peak heating load in Lawrence, Kansas [11-14]. Based on simulation under Dayton climate, Kissock found that the peak and annual cooling loads were reduced by $19 \%$ and 13\%, respectively [22]. Using EnergyPlus, Tabares reported a peak cooling reduction of $4 \%$ in the peak month of July in Phoenix [18]. A recent simulation study performed for major Australian cities indicted that the energy savings from a typical whole house is much less than a small scale room house [28]. This explains the low savings potential of PCM in this study. The results from this study are overall in agreement with the results obtained from the literature. 


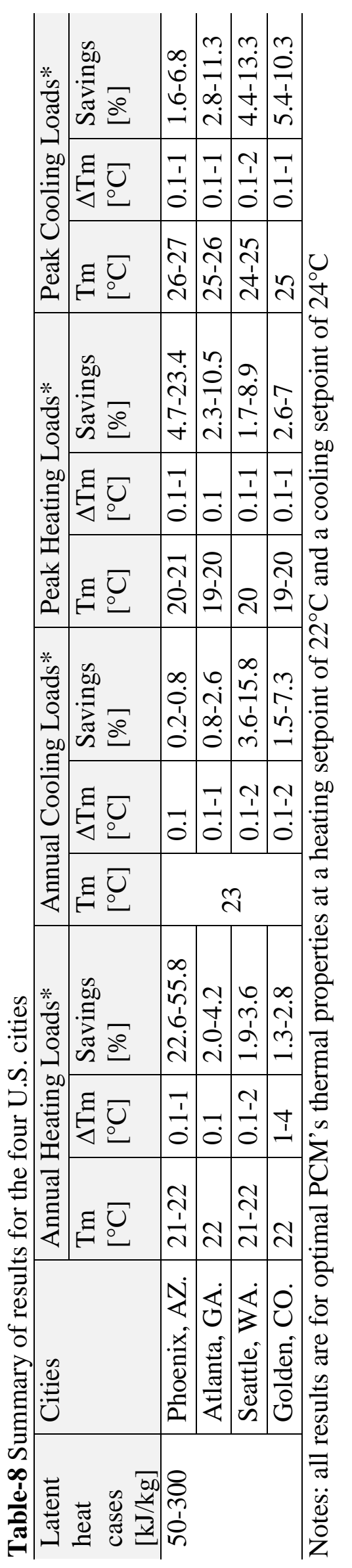




\section{Conclusion}

In this research work, a new TRNSYS numerical module "Type-285" for modeling PCM-enhanced wall was developed and validated using experimental results. The validated module has been utilized to study different PCM's design determinates including PCM's location within the wall assembly, orientation and PCM's thermal properties. Results from a single climate indicated that the best location for PCM layer is when located close to the controlled environment; to the interior side of the building. This conclusion is in line with literature as has been demonstrated in several studies [54-58]. Regardless of orientation, the thermal performance of PCM is equally valuable with the highest performance when PCM is embedded in all walls. This concludes that more PCM's surface area is thermally beneficial.

Four U.S. representative climates: Phoenix AZ, Atlanta GA, Seattle WA and Golden CO, were selected for evaluating thermal performance of PCM when placed to interior side of the wall. A wide variation of PCM's thermal properties was simulated. For this particular case study, it is concluded that PCM has undergone low performance. The results summarized in Table 8 are, however, found to be in agreement with a literature summarized in Table 1. The results show that a maximum saving of $0.8-15.8 \%$ is achieved on annual cooling load with the lowest being observed in Phoenix AZ and the highest in Seattle WA. For heating dominated climates, the savings on annual heating load is insignificant being less than $4 \%$. The saving in peak loads show more potential than annual loads for some climates. The maximum savings in peak cooling load range from 6.8-13.3\% with the lowest in Phoenix AZ and the highest in Seattle WA. The maximum savings in peak heating load range from $7-10.5 \%$ with the lowest in Golden $\mathrm{CO}$ and the highest in Seattle WA. 
Another objective of this study was to determine the optimal PCM's thermal properties. This, however, has shown to be a challenging task since no universal guidelines can be drawn for optimal PCM's thermal properties across climates. This is pertained to the latent heat of PCMs, the building's operational characteristics (heating and cooling setpoints and internal load profiles), the climate, and the intended design objective. Therefore, the PCM's thermal properties should carefully be selected. In this regard, the following can be concluded about the optimal PCM's thermal properties:

- For maximum savings in annual heating load, the optimal melting temperature should either be at a heating setpoint of $22^{\circ} \mathrm{C}$ or a degree lower, depending on the PCM's latent heat. A narrow melting range of $0.1-2^{\circ} \mathrm{C}$ is favorable with exception of Golden climate which demands $1-4^{\circ} \mathrm{C}$ melting range.

- For maximum savings in annual cooling load, the optimal melting temperature should be a degree lower than the cooling setpoint across all climates. The corresponding melting temperature goes from a very tight value of $0.1{ }^{\circ} \mathrm{C}$ in a severe summer climate to a little wider melting range of $2^{\circ} \mathrm{C}$ in mild summer climates.

- For maximum savings in peak heating load, the optimal melting temperature is $1-3^{\circ} \mathrm{C}$ below the heating setpoint depending on the latent heat and climate with a melting range of $0.1-1^{\circ} \mathrm{C}$.

- For maximum savings in peak cooling load, the melting temperature should generally be between $24-26^{\circ} \mathrm{C}$ for mild summer climate and $26-27^{\circ} \mathrm{C}$ for cooling dominated climate with a melting range should be in the range of $0.1-2^{\circ} \mathrm{C}$ depending on climate.

Further research is needed to enhance the thermal performance of PCM in residential buildings. In particular, the charging and discharging process should clearly be evaluated under 
dynamic environmental conditions. Ideally, the charging and discharging process should occur on a daily bases for maximum benefits. In summer mild climates, the PCM can be flushed with outside cooled air via natural ventilation during night to prepare the PCM for the next hot day cycle. In winter cold climates, solar harvesting techniques should be fully exploited to store the solar heat for later night use. This could be achieved using direct solar gain techniques such as high south fenestration systems or using advanced TROMBE PCM-enhanced walls.

\section{Acknowledgements}

This study is part of an ongoing research at University of Colorado Boulder funded by US National Science Foundation (EFRI-1038305). The first author would like to thank Sultan

Qaboos University for its continuous encouragement and support of research activities. In particular, he is grateful to Prof. Khalifa Al-Jabri for providing access to TRNSYS simulation package to perform this study.

\section{Nomenclature}

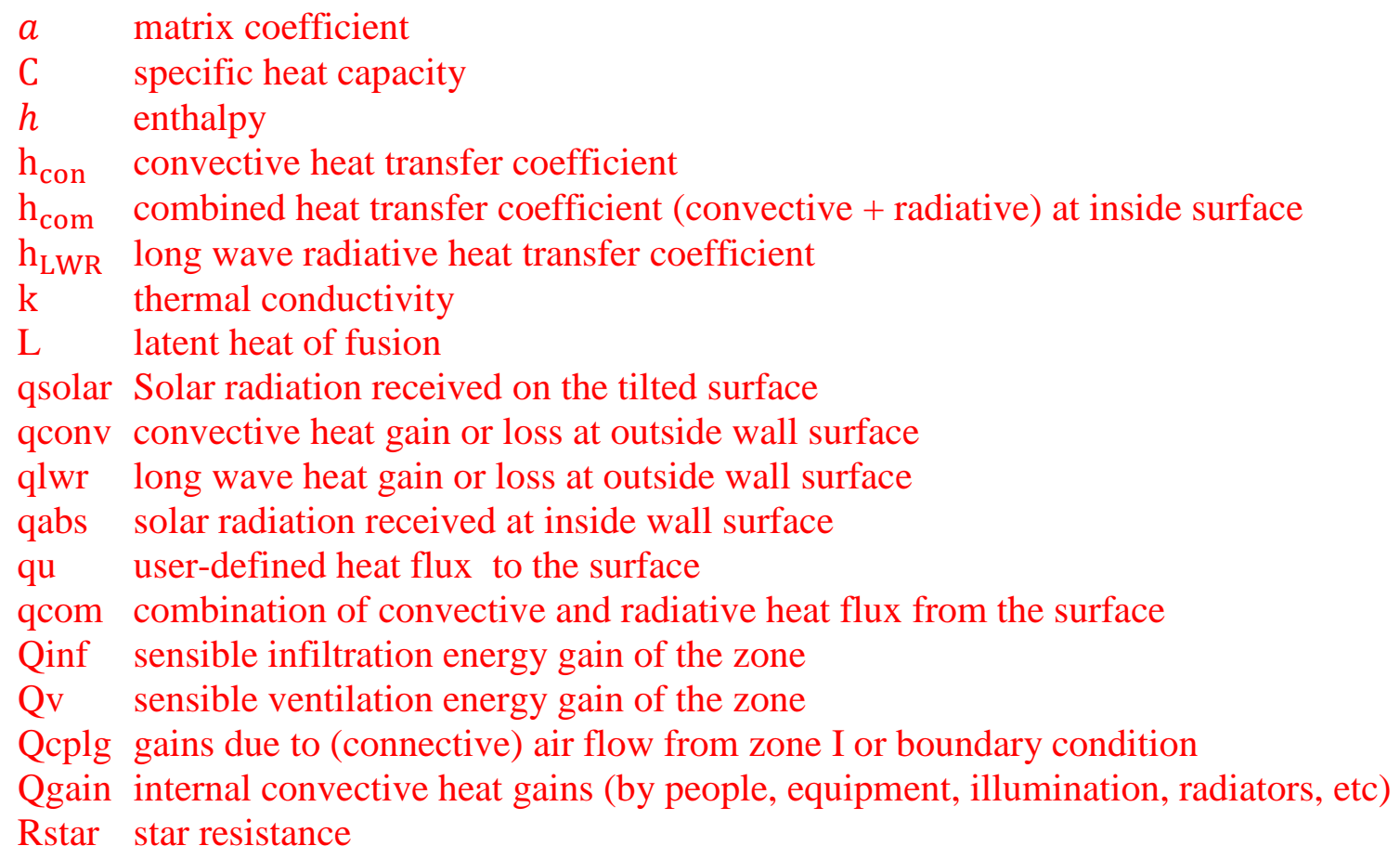




\begin{tabular}{|c|c|}
\hline $\mathrm{T}$ & Temperature \\
\hline $\mathrm{T}_{\text {fsky }}$ & fictive sky temperature \\
\hline $\mathrm{T}_{\text {star }}$ & star node temperature of the zone \\
\hline $\begin{array}{l}\mathrm{T}_{\mathrm{a}} \\
t\end{array}$ & indoor air temperature of the zone \\
\hline $\begin{array}{l}t \\
\mathrm{~V}\end{array}$ & time \\
\hline $\mathrm{V}$ & wind velocity \\
\hline $\mathrm{x}$ & space distance \\
\hline \multicolumn{2}{|c|}{ Greek Symbols } \\
\hline$\in$ & half range temperature \\
\hline$\rho$ & density \\
\hline \multicolumn{2}{|c|}{ Subscripts } \\
\hline $\mathrm{e}$ & east node \\
\hline 1 & liquid state \\
\hline $\mathrm{m}$ & melting \\
\hline $\mathrm{p}$ & point node \\
\hline $\mathrm{s}$ & solid state \\
\hline s_ext & exterior surface \\
\hline s_int & interior surface \\
\hline w & west node \\
\hline \multicolumn{2}{|c|}{ Superscripts } \\
\hline & $\begin{array}{l}\text { indicates an iteration step } \\
\text { indicate a time step }\end{array}$ \\
\hline
\end{tabular}

\section{References}

[1] R. Baetens, B.P. Jelle, A. Gustavsen, Phase change materials for building applications: A state-of-the-art review, Energy and Buildings, 42 (9) (2010) 1361-1368.

[2] A.M. Khudhair, M.M. Farid, A review on energy conservation in building applications with thermal storage by latent heat using phase change materials, Energy Conversion and Management, 45 (2) (2004) 263-275.

[3] Y. Zhang, G. Zhou, K. Lin, Q. Zhang, H. Di, Application of latent heat thermal energy storage in buildings: State-of-the-art and outlook, Building and Environment, 42 (6) (2007) 2197-2209.

[4] V.V. Tyagi, D. Buddhi, PCM thermal storage in buildings: A state of art, Renewable and Sustainable Energy Reviews, 11 (6) (2007) 1146-1166.

[5] A. Pasupathy, R. Velraj, R.V. Seeniraj, Phase change material-based building architecture for thermal management in residential and commercial establishments, Renewable and Sustainable Energy Reviews, 12 (1) (2008) 39-64.

[6] N. Zhu, Z. Ma, S. Wang, Dynamic characteristics and energy performance of buildings using phase change materials: A review, Energy Conversion and Management, 50 (12) (2009) 31693181 .

[7] F. Kuznik, D. David, K. Johannes, J.-J. Roux, A review on phase change materials integrated in building walls, Renewable and Sustainable Energy Reviews, 15 (1) (2011) 379-391. 
[8] L.F. Cabeza, A. Castell, C. Barreneche, A. de Gracia, A.I. Fernández, Materials used as PCM in thermal energy storage in buildings: A review, Renewable and Sustainable Energy Reviews, 15 (3) (2011) 1675-1695.

[9] D. Zhou, C.Y. Zhao, Y. Tian, Review on thermal energy storage with phase change materials (PCMs) in building applications, Applied Energy, 92 (0) (2012) 593-605.

[10] E. Osterman, V.V. Tyagi, V. Butala, N.A. Rahim, U. Stritih, Review of PCM based cooling technologies for buildings, Energy and Buildings, 49 (0) (2012) 37-49.

[11] M. Zhang, M.A. Medina, J.B. King, Development of a thermally enhanced frame wall with phase-change materials for on-peak air conditioning demand reduction and energy savings in residential buildings, International Journal of Energy Research, 29 (9) (2005) 795-809.

[12] M.A. Medina, J.B. King, M. Zhang, On the heat transfer rate reduction of structural insulated panels (SIPs) outfitted with phase change materials (PCMs), Energy, 33 (4) (2008) 667-678.

[13] Y. Fang, M.A. Medina, Proposed Modifications for Models of Heat Transfer Problems Involving Partially Melted Phase Change Processes, Journal of ASTM International, 6 (9) (2009).

[14] A.C. Evers, M.A. Medina, Y. Fang, Evaluation of the thermal performance of frame walls enhanced with paraffin and hydrated salt phase change materials using a dynamic wall simulator, Building and Environment, 45 (8) (2010) 1762-1768.

[15] K.O. Lee, E. University of Kansas. Civil, A. Engineering, Using Hydrated Salt Phase Change Materials for Residential Air Conditioning Peak Demand Reduction and Energy Conservation in Coastal and Transitional Climates in the State of California, University of Kansas, 2013.

[16] K. Muruganantham, Application of Phase Change Material in Buildings: Field Data vs. EnergyPlus Simulation, Arizona State University, 2010.

[17] K. Biswas, P.W. Childs, J.A. Atchley, Field Testing of Nano-PCM Enhanced Building Envelope Components, in, 2013, pp. Medium: ED.

[18] P.C. Tabares-Velasco, C. Christensen, M. Bianchi, Verification and validation of EnergyPlus phase change material model for opaque wall assemblies, Building and Environment, 54 (0) (2012) 186-196.

[19] Affiliated Engineers, Preliminary analysis of PCM strategies, "URL: www.phasechange.com/Research\%20Library/OSH_JC_PCM_Analysis.pdf", [Accessed: April/09/2014].

[20] Y.-B. Seong, J.-H. Lim, Energy Saving Potentials of Phase Change Materials Applied to Lightweight Building Envelopes, Energies, 6 (10) (2013) 5219-5230.

[21] A.L.S. Chan, Energy and environmental performance of building façades integrated with phase change material in subtropical Hong Kong, Energy and Buildings, 43 (10) (2011) 29472955.

[22] J. Kelly Kissock, J. Michael Hannig, T.I. Whitney, M.L. Drake, Testing and simulation of phase change wallboard for thermal storage in buildings, in: J.M. Morehouse, R.E. Hogan (Eds.) International Solar Energy Conference, American Society of Mechanical Engineers, Albuquerque, 1998.

[23] K. Kissock, Thermal Load Reduction from Phase-Change Building Components in Temperature Controlled Buildings, in: ASME International Solar Energy Conference, Madison, WI, June., 2000. 
[24] C. Stetiu, H.E. Feustel, Phase change wallboard and mechanical night ventilation in commercial buildings, in: Lawrence Berkeley Laboratory Report, University of California, Berkeley, 1998.

[25] K.W. Childs, T.K. Stovall, Potential Energy Savings Due to Phase Change Material in a Building Wall Assembly: An Examination of Two Climates, in, 2012, pp. Medium: ED.

[26] A.K. Athienitis, C. Liu, D. Hawes, D. Banu, D. Feldman, Investigation of the thermal performance of a passive solar test-room with wall latent heat storage, Building and Environment, 32 (5) (1997) 405-410.

[27] B.M. Diaconu, M. Cruceru, Novel concept of composite phase change material wall system for year-round thermal energy savings, Energy and Buildings, 42 (10) (2010) 1759-1772.

[28] M. Alam, H. Jamil, J. Sanjayan, J. Wilson, Energy saving potential of phase change materials in major Australian cities, Energy and Buildings, 78 (0) (2014) 192-201.

[29] U.S.A. Department of Energy New Features in Version 2.0.0, URL: http://apps1.eere.energy.gov/buildings/energyplus/energyplus_archives.cfm\#v4, [Accessed: October/23/2012].

[30] D. Bradley, M. Kummert, New Evolutions in TRNSYS-A Selection of Version 16 Features, in: Proceedings of Building Simulation 2005: 9th Conference of International Building Performance Simulation Association, Montréal, Canada,, 2005.

[31] University of Strathclyde - Energy Systems Research Unit - ESP-r, URL: http://www.esru.strath.ac.uk/Programs/ESP-r.htm [Accessed: October/23/2012].

[32] S.N. Al-Saadi, Z. Zhai, Modeling phase change materials embedded in building enclosure: A review, Renewable and Sustainable Energy Reviews, 21 (0) (2013) 659-673.

[33] A. Bontemps, M. Ahmad, K. Johannès, H. Sallée, Experimental and modelling study of twin cells with latent heat storage walls, Energy and Buildings, 43 (9) (2011) 2456-2461.

[34] S. Sadasivam, F. Almeida, D. Zhang, A.S. Fung, An Iterative Enthalpy Method to Overcome the Limitations in ESP-r's PCM Solution Algorithm, ASHRAE Transactions, 117 (2) (2011) 100-107.

[35] Y. Dutil, D. Rousse, S. Lassue, L. Zalewski, A. Joulin, J. Virgone, F. Kuznik, K. Johannes, J.-P. Dumas, J.-P. Bédécarrats, A. Castell, L.F. Cabeza, Modeling phase change materials behavior in building applications: Comments on material characterization and model validation, Renewable Energy, 61 (0) (2014) 132-135.

[36] TRANSSOLAR Energietechnik GmbH, TRNSYS 16: A TRaNsient SYstem Simulation program, Volume 5: Mathematical Reference, in, 2007.

[37] S.V. Patankar, Numerical heat transfer and fluid flow, Hemisphere Pub. Corp., 1980.

[38] V.R. Voller, An Overview of Numerical Methods for Solving Phase Change Problems, in: W.J. Minkowycz, E.M. Sparrow (Eds.) Advances in numerical heat transfer, Taylor \& Francis, 1997, pp. 341-380.

[39] S.N. Al-Saadi, Z. Zhai, Systematic evaluation of mathematical methods and numerical schemes for modeling PCM-enhanced building enclosure, Energy and Buildings, 92 (0) (2015) 374-388.

[40] C.R. Swaminathan, V.R. Voller, On the enthalpy method, Int. J. Num. Meth. Heat Fluid Flow, 3 (1993) 233-244.

[41] N. Shukla, A. Fallahi, J. Kosny, Performance characterization of PCM impregnated gypsum board for building applications, Energy Procedia, 30 (0) (2012) 370-379.

[42] C. Ramprasad, L. Edwin S., F. Daniel E., An Enhanced Simulation Model for Building Envelopes with Phase Change Materials, ASHRAE Transactions, 119 (2) (2013). 
[43] F. Kuznik, J. Virgone, K. Johannes, Development and validation of a new TRNSYS type for the simulation of external building walls containing PCM, Energy and Buildings, 42 (7) (2010) 1004-1009.

[44] DuPont Global Website, URL: http://energain.co.uk/Energain/en_GB/index.html, [Accessed: June/04/2014].

[45] R. Hendron, C. Engebrecht, Building America House Simulation Protocols (Revised), in: Related Information: Supercedes September 2010 version., 2010, pp. Medium: ED; Size: 88 pp. [46] J. Kneifel, NIST TN - 1765: Prototype Residential Building Designs for Energy and Sustainability Assessment, in, 2012.

[47] Armin Rudd, J. Hugh I. Henderson, Daniel Bergey, Don B. Shirey, ASHRAE, Energy Efficiency and Cost Assessment of Humidity Control Options for Residential Buildings : ASHRAE 1449-RP Final Report, Building Science Corp., CDH Energy Corp., and University of Central Florida / Florida Solar Energy Center,, 2013.

[48] TRANSSOLAR Energietechnik GmbH, TRNSYS 16: A TRaNsient SYstem Simulation program, Volume 6: Multizone Building modeling with Type56 and TRNBuild, in, 2007.

[49] H. Liu, H.B. Awbi, Performance of phase change material boards under natural convection, Building and Environment, 44 (9) (2009) 1788-1793.

[50] J.A. Palyvos, A survey of wind convection coefficient correlations for building envelope energy systems' modeling, Applied Thermal Engineering, 28 (8-9) (2008) 801-808.

[51] American Society of Heating Refrigerating Air-Conditioning Engineers, 2005 ASHRAE Handbook: Fundamentals, ASHRAE, 2005.

[52] R. American Society of Heating, A.-C. Engineers, A.N.S. Institute, Energy Efficient Design of Low Rise Residential Buildings, American Society of Heating, Refrigerating and AirConditioning Engineers, 2004.

[53] N. Soares, J.J. Costa, A.R. Gaspar, P. Santos, Review of passive PCM latent heat thermal energy storage systems towards buildings' energy efficiency, Energy and Buildings, 59 (0) (2013) 82-103.

[54] T.K. Stovall, J.J. Tomlinson, What are the Potential Benefits of Including Latent Storage in Common Wallboard?, Journal of Solar Energy Engineering, 117 (4) (1995) 318-325.

[55] K. Peippo, P. Kauranen, P.D. Lund, A multicomponent PCM wall optimized for passive solar heating, Energy and Buildings, 17 (4) (1991) 259-270.

[56] D.A. Neeper, Thermal dynamics of wallboard with latent heat storage, Solar Energy, 68 (5) (2000) 393-403.

[57] N. Soares, A.R. Gaspar, P. Santos, J.J. Costa, Multi-dimensional optimization of the incorporation of PCM-drywalls in lightweight steel-framed residential buildings in different climates, Energy and Buildings, 70 (0) (2014) 411-421.

[58] J. Wang, E. Long, W. Qin, L. Xu, Ultrathin envelope thermal performance improvement of prefab house by integrating with phase change material, Energy and Buildings, 67 (0) (2013) 210-216. 